\title{
Poster Session 1:
}

Chairs: Prof.Dr. Marcelo Brocchi and Profa.Dra. Ana Olívia de Souza

\section{LARGE SCALE GENE E|PRESSION ANALYSIS OF ADULT MURINE THYMUS TREATED in vitro WITH INTERLEUKIN-7}

\author{
Paula MO, Zárate-Bladés CR, Silveira ELV, Fachin AL, Junta CM, Sandrin-Garcia P, \\ Magalhães DAR, Macedo C, Silva CL, Donadi EA, Sakamoto-Hojo ET \& Passos GAS \\ Molecular Imunogenetics Group. Faculty of Medicine of Ribeirão Preto. University of São Paulo \\ marina@rpm.fmrp.usp.br, passos@rge.fmrp.usp.br
}

The maturation of $\mathrm{T}$ lymphocytes from progenitor cells has defined stages and is mainly associated to recombination and somatic expression of TCR genes, cellular proliferation, selection induced by antigens and functional capacities. The three-dimensional structure of thymus, besides cytokines action, is quite important during the process of thymocyte maturation. Unlike suspension cultures, ATOC (Adult Thymus Organ Culture) preserves the thymus architecture and faithfully represents the microenvironment where differentiation of thymocytes takes place. Therefore, the ATOC technique is considered the ideal model system for the study of the effects of cytokines on thymocytes. Interleukin-7 plays an essential role during thymocyte maturation process, as to assure the survival and to stimulate V(D)J recombination of TCR genes. The analysis of alterations in the gene expression patterns of IL-7-treated ATOC using cDNA microarrays is the main goal of this project. Moreover, we intend to evaluate if IL-7 modulates V(D)J recombination of TCRVB8.1 in ATOC by a semiquantitative Southern Blotting. Using specialized softwares to analyse microarray data, we intend to select "new" differentially expressed genes (repressed or overexpressed) in thymocytes under the action of IL-7.

Keywords: Thymocytes. Interleukin-7. Microarrays.

Support: CNPq (133863/03-4), FAPESP (99/12135-9)

\section{USING CDNA MICROARRAYS TO EVALUATE THE MODULATION OF GENE EXPRESSION IN T CD4+ HUMAN LYMPHOCYTES (JURKAT E6-1) BY INTERLEUKIN-12}

\author{
Wowk PF, Baião AMT, Fachin AL, Junta CM, Sandrin-Garcia P, Mello SS, Silva CL, Donadi EA, \\ Sakamoto-Hojo ET \& Passos GAS \\ Grupo de Imunogenética Molecular. Faculdade de Medicina de Ribeirão Preto - USP.
}

The interleukin-12 is an important mediator of the early innate immune response to intracellular microbes and is a key inducer of cell-mediated immunity. It displays several in vitro activities, like protective immunity against infectious agents and perhaps also against tumor cells. Produced mainly by macrophages and dendritic cells, IL-12 stimulates the production of IFN- $\gamma$ by natural killer cells and T lymphocytes, the differentiation of T $\mathrm{CD}^{+}$helper lymphocytes into IFN- $\gamma$ - producing Th1, and enhances the cytolytic 5 function of activated NK cells and $\mathrm{CD}^{+}$cytolytic T lymphocytes. Our aim is to compare the gene expression patterns of Jurkat E6-1 T cells line cultured with IL-12 during 6,12 and 18 hours at different concentrations $(10,1 \mathrm{e} 0,1 \mathrm{ng} / \mathrm{ml}$ of culture) or in the absence of IL-12 (control). The total RNA of the Jurkat E6-1 cells (IL-12 treated or controls) is converted to cDNA by reverse transcription in the presence of $33 \mathrm{p}$ (radioactive complex probes) and hybridized to nylon cDNA microarrays containing $780 \mathrm{cDNA}$ sequences related to the immune system. Using bioinformatic softwares applied to the microarray data analysis, we intent to point out the differentially expressed genes between IL-12 treated and control cells and to select those implicated in the pleiotropic effect of this cytokine.

Keywords: T CD4+ lymphocytes. Interleukin-12. cDNA Microarrays.

Financial support: CNPq (130699/03-9), FAPESP (99/12135-9) 


\title{
MNCF, A MEDIATOR INFLAMMATORY RESISTANT TO THE ACTION OF GLUCOCORTICOIDS. SECRETION BY MURINE MACROPHAGES
}

\author{
Toledo KA \& Roque-Barreira MC \\ Departamento de Biologia Celular e Bioagentes Patogênicos. Faculdade de Medicina de Ribeirão Preto (USP). \\ Karina@rpm.fmrp.usp.br
}

MNCF was formerly characterized as a D-galactose binding lectin, derived from rat peritoneal macrophages, stimulated with LPS. MNCF induces neutrophil migration, an activity that is resistant to the anti-inflammatory effect of dexamethasone and inhibited by D-galactose. Based on these peculiarities we suggested that MNCF could be a new mediator of the inflammatory process. In the present study we verified that the supernatant of monolayers of mouse peritoneal macrophages, stimulated with LPS, was endowed of MNCF activity, which was recovered in a fraction adsorbed to melibiose-agarose. This fraction presented an electrophoretic profile coincident with that of rat MNCF (majoritary bands with 69 and $59 \mathrm{kDa}$ ). It was able to induce neutrophil migration, an activity characterized as dose-dependent $(3 \mathrm{ug} / \mathrm{ml}$ was the optimal concentration) and as resistant to the pre-treatment of test-mice with dexamethasone. The preparation was denoted MNCF-c and assayed for the known properties of rat MNCF. MNCF-c bound to laminin, an interaction inhibited by alfa-galactosides. P388-D1 line of mouse macrophages, adapted to a serum free medium (Macrophage-SFM) also secreted a melibiose-binding protein with MNCF features. It was denoted MNCF-P388 and characterized as able to induce neutrophil migration resistant to the dexamethasone anti-inflammatory effect, and presenting a single band $(69 \mathrm{kDa})$ on SDS-PAGE. We are doing efforts to resolve the primary structure of MNCF molecule from different origins. The investment is justified by the potential relevance of MNCF activity in several diseases, in which the control of neutrophil infiltration is crucial.

Keywords: MNCF. Glucorticoids. Inflammation.

Support: CAPES, FAPESP

\section{DIFFERENTIAL GENE EXPRESSION ANALYSIS OF NOD MOUSE LYMPHOID TISSUES DURING THE EMER- GENCE OF TYPE 1 DIABETES MELLITUS}

\author{
Silveira ELV, Zárate-Bladés CR, Paula MO, Fachin AL, Junta CM, Sandrin-Garcia P, Silva CL, \\ Sakamoto-Hojo ET, Donadi EA \& Passos GAS \\ Molecular Immunogenetics Group. Faculty of Medicine of Ribeirão Preto. University of São Paulo. \\ eduardo@rpm.fmrp.usp.br, passos@rgr.fmrp.usp.br
}

The classical animal model that reproduce the main features of type 1 human diabetes mellitus is the nonobese diabetic (NOD) mouse, who develops this autoimmune disease nearly $15^{\text {th }}$ week of life. In the early stage of diabetes occur a cellular infiltrate that affects the islets pancreatic $\beta$ cells near $4^{\text {th }}$ week of age. The main cells that participate in this inflammation process are macrophages and dendritic cells. These cells, also called APCs, capture $\beta$ cells autoantigens those may be released during turnover of $\beta$ cells, and present them to T lymphocytes. If there be T lymphocyte activation and the presence of Th1 cytokines in this microenvironment, certainly it will be created a immune response against the insulin producing cells but without significance destruction in this stage of life. This attack becomes more aggressive near $15^{\text {th }}$ week, when almost all the $\beta$ cells are destroyed and overt diabetes. Our aim is to compare the differential gene expression in the thymus and spleen of preautoimmune NOD mice (newborn) and autoimmune animals ( $4^{\text {th }}$ and $16^{\text {th }}$ weeks old). For this, we are using the cDNA-microarray method to analyze important genes to the immune system such as cytokines, cytokines receptors, MHC, transcription factors, apoptosis, cell cycle among others. The use of bioinformatic softwares applied to the microarray data analysis permit to evidence candidate genes implicated in the type 1 diabetes mellitus in NOD mice.

Keywords: NOD. Diabetes. cDNA-Microarrays.

Support: CAPES, FAPESP (99/12135-9) 


\title{
THE ROLE OF LEUKOTRIENES IN ORAL TOLERANCE INDUCTION
}

\author{
Frantz FG ${ }^{1}$, Russo $\mathrm{M}^{2}$, Nomizo $\mathrm{A}^{3}$ \& Faccioli $\mathrm{LH}^{3}$ \\ ${ }^{1}$ Departamento de Bioquímica e Imunologia. Faculdade de Medicina de Ribeirão Preto-USP, ${ }^{2}$ Departamento de Imunologia. \\ Instituto de Ciências Biomédicas-USP, ${ }^{3}$ Departamento de Análises Clínicas, Toxicológicas e Bromatológicas. \\ Faculdade de Ciências Farmacêuticas de Ribeirão Preto-USP. \\ frantz@fcfrp.usp.br
}

Lipid mediators generated by the metabolism of arachidonic acid are collectively termed eicosanoids. The pathway of 5-lipoxygenase catalyzes a reaction that converts arachidonic acid to leukotriene- $\mathrm{B}_{4}$ and cysleukotrienes. There is little knowledge of the eicosanoids participation on peripheral tolerance phenomenon. Oral tolerance is known as the periphery immunological unresponsiveness induced by oral administration of exogenous antigen. It is considered that the reduction of cellular and humoral immunological responses in the state of oral tolerance is mainly due to the reduced responses of antigen-specific $\mathrm{T}$ cells. Several mechanisms for the reduction of $\mathrm{T}$ cell response have been proposed, such as clonal deletion, clonal anergy, selective expansion of regulatory $T$ cells and down regulation of $\mathrm{T}_{\mathrm{H}} 2$ immunity due to immune deviation toward $\mathrm{T}_{\mathrm{H}} 1$ pathway. In this work we have studied the role of leukotrienes in the induction of oral tolerance to ovalbumin (OVA). For this, we used the MK886 compound that inhibits the 5-lipoxygenase activating protein (FLAP) required for leukotrienes biosynthesis. We conclude that inhibition of leukotrienes production during OVA gavage, immunization and challenge didn't abrogate the oral tolerance induction, demonstrated by inhibition of spleen cells proliferation and total antibodies production. Above all, we conclude that MK 886 treatment induced an immune deviation towards a $\mathrm{T}_{\mathrm{H}} 1$ pattern, as indicated by enhanced IgG2a and IFN- $\gamma$ production. Than, we can suggest that leukotrienes are important mediators involved in oral tolerance mechanisms regulation.

Keywords: Leukotrienes. Oral Tolerance. Immunoregulation.

Supported: CNPq.

\section{THE ROLE CHEMOKINES IN KIDNEY ALLOGRAFT}

\author{
Crispim JCOF ${ }^{1}$, Santana JS ${ }^{2}$, Saber $\mathrm{LTS}^{3}, \mathrm{Costa}_{\mathrm{RS}}^{4}$, \& Donadi EA ${ }^{1}$
}
${ }^{1}$ Divisão de Imunologia Clínica. Departamento de Clínica Médica. ${ }^{2}$ Laboratório de Imunoparasitologia. Departamento de Bioquími- ca e Imunologia. ${ }^{4}$ Departamento de Patologia. Faculdade de Medicina de Ribeirão Preto-USP.
${ }^{3}$ Unidade de Transplante Renal do Hospital das Clínicas-FMRP-USP.
janacrispim@rpm.fmrp.usp.br

Chemokines and chemokines receptors are involved in the at some stage during development of allograft rejection. Locally secreted chemokines mediate leukocyte recruitment during the initiation and amplification phase de renal inflammation. In turn, the infiltrating leukocytes contribute to renal damage by releasing inflammatory and profibrotic factors. Rapid down modulation of the chemokine signal will support resolution of acute inflammation. Whereas progression occurs if ongoing or repeated renal injury maintains continuous local chemokine secretion and leukocyte influx into the glomerulus or the interstitial space.In the study, we will perform biopsies from 30 patients using immunohistochemistry to investigate the presence chemokines and chemokine receptors RANTES, MIG, MCP-1, MIP-1 $\alpha$, CXCR3 and CCR5 in the kidney allograft. The biopsies wiil be taken in the first 6 months and $12^{\text {th }}$ month following transplantation.

Keywords: Chemokines. kidney allograft. Biopsies.

Auxílio: CAPES 


\title{
PRODUCTION OF HUMAN MONOCLONAL ANTIBOTHROPIC ScFV ISOLATED FROM A NONIMMUNIZED PHAGE LIBRARY
}

\author{
Tamarozzi MB, Soares SG \& Barbosa JE \\ Departamento de Bioquímica e Imunologia. Faculdade de Medicina de Ribeirão Preto-USP. \\ mirela@rpm.fmrp.usp.br
}

Snakes of the genus Bothrops are widespread in Latin America, and are responsible for the majority of snakebites in this region. In Brazil, Bothrops ssp cause more than $70 \%$ of accidents by snakebites. Immune passive therapy is the treatment of choice for snake poisoning. This treatment requires production of high-titer antivenoms by animals, usually horses. However, due to the high concentrations of potent toxins in some snake venoms, this imunization may prove difficult. Moreover, the use of heterologous serum frequently causes adverse reactions in humans. Alternatively, construction of libraries of human antibody fragments ( $\mathrm{scFv}$ ) displayed on the surface of filamentous bacteriophage and the selection of antibodies by affinity for antigens from snake venom offers a powerful method of generating new tools for clinical application. We used a large nonimmune human scFv library Griffin.1 (MRC, Cambridge, UK) for selection of scFv against antigens present in Bothrops jararacussu venom. Policlonal phage-antibodies were obtained through four rounds of selection on venomcoated immunotubes and subsequent amplification in TG1 E. coli bacteria. Plates of monoclonal phage-antibodies were produced and the positive clones will be used to obtain soluble scFv. The use of human antibothropic scFvs may provide a valuable tool against poisoning by Bothrops venom.

Keywords: Antivenom. Bothrops. Phage Display.

This study was supported by grants from FAPESP and CNPq

\section{PRODUCTION OF HUMAN MONOCLONAL ANTIBODIES (scFV) BY PHAGE DISPLAY TECHNOLOGY AGAINST ELAPIDIC VENOM}

\author{
Oliveira JG, Soares SG \& Barbosa JE \\ Departamento de Bioquímica e Imunologia. Faculdade de Medicina de Ribeirão Preto-USP \\ juliana@rpm.fmrp.usp.br
}

Heterologous antibody administration has been the treatment of choice for snakebite victims. This practice requires the production, normally by horses immunizing, of a high-titer anti-venom serum, which takes a long time to be obtained. In addition, due to the large amount of heterologous proteins administered, serum therapy may induce adverse reactions. The phage display technology offers a new possibility for producing human antibodies that could be used in immune therapy. In this study, we used a large human nonimmune library Griffin.1 (MRC, Cambridge, UK) to produce phage antibodies against Micrurus ibiboboca venom, one of the species responsible for most elapidics poisonings in Brazil. The phage repertoire was panned using immunotubes coated with a solution of crude venom. After four rounds of selection, policlonal phage- antibodies were screened for its capacity of binding to the antigen by ELISA. The second, third and fourth rounds showed to be positive for the antigen and will be used to produce monoclonal phage antibodies. The best ligands will be expanded to produce monoclonal scFv clones. A clone or a pool of clones producing scFv antibodies will be tested for its ability in neutralizing elapidic venon. This strategy could be used to substitute the heterologous immune therapy.

Keywords: Phage Display. Elapidic Venom. Immune Therapy.

This study was supported by grants from FAPESP and CAPES 


\title{
EFFECT OF Rhipicephalus sanguineus (LATREILLE, 1806) TICKS SALIVA ON MICE DENDRITIC CELL FUNCTION AND MIGRATION
}

\author{
Oliveira CJF, Cavassani KA, Aliberti JCS, Silva JS \& Ferreira BR \\ Departamento de Bioquímica e Imunologia. Faculdade de Medicina de Ribeirão Preto-USP \\ Carlo@rpm.fmrp.usp.br
}

Ticks are a highly specialized group of obligate bloodsucking ectoparasitic arthropods that feed on vertebrates. Besides being able to transmit patogens that cause diseases of veterinary and human economic importance, its feeding causes direct damage to the skin. Ticks saliva contains a variety of pharmacologically active molecules that, when inoculated for many days in the feeding site modulates the host immune response and facilitates propagation and development of this parasite. Our group has been studying tick-host interaction and has showed that mice, as dogs (natural host), are naturally susceptible to $R$. sanguineus ticks and its saliva inhibits cytokine production, diferentiation and maturation of mice dendritic cells (DCs). Since DCs have a great importance in modulation and assembly of the primary immune response to many pathogens, the present work intends to study the effects of $R$. sanguineus ticks' saliva on mice DC function and migration. To evaluate DC's migration in the presence of saliva, in vitro, we will perform transwell and boyden microchamber migration assays, and, for in vivo analysis, local treatment with saliva during sensitization with FITC will be used to verify DC's migration to lymph nodes. In order to assess DC's function in presence of saliva, cellular proliferation and cytokines production will be assayed after DCs differentiation with IL-4 and GM-CSF. Our results will extend the knowledge on saliva modulation effects in the immune system, raising the possibility of development of new products for tick control and immunosuppressive drugs.

Keywords: Ticks. Dendritic Cell. Migration.

Supported by FAPESP, CNPq

\section{STUDY OF VIRAL INTERFERENCE BETWEEN DENGUE 2 AND YELLOW FEVER VIRUSES}

\author{
Abrão EP, Gomes-Ruiz AC \& Fonseca BAL \\ Programa de Pós-graduação em Imunologia Básica e Aplicada - Bioagentes Patogênicos. Faculdade de Medicina de Ribeirão Preto- \\ USP. emiliana@rpm.fmrp.usp.br
}

Dengue is the most important disease caused by an arbovirus in the world. Annually, the infections with the dengue viruses cause more than 100 million cases of classic dengue and more than 500.000 cases of dengue hemorragic fever/dengue shock syndrome (Monath, 1994). Another arbovirus infection of great importance to the public health is yellow fever, an acute infectious disease prevalent in the Americas and Africa. Both, the urban and rural modalities are caused by the yellow fever virus, an arbovirus transmitted by certain mosquitos, including Aedes aegypti, the same vector responsible for dengue transmission. Although a safe vaccine is available for more than 60 years, there has been an increase in the number of infected people during the last two decades. Historically, dengue epidemics occur in Asia but, in the same area there is no description of yellow fever. Among the hypotheses that try to explain this fact, it has already been pointed out the possibility of cross immunity and decreased vectorial capacity of the Aedes aegypti in relation to the yellow fever. None of these hypothesis have been proved yet. The objective of this project is to investigate this phenomenon through the study of the interference of a virus in the replication of another. Therefore, we will test our hypothesis through the infection of mosquito cell cultures with these two viruses and analyze the influence that each one of them exercises in the infection of the other one through the use of indirect immunofluorescence assay and Real-Time PCR. 


\title{
Poster Session 2
}

\author{
Chairs: Prof.Dr. Vanderlei Rodrigues and Profa.Dra. Arlete A Martins Coelho Castelo
}

\section{CELULAR CHARACTERIZATION AND DETECTION OF CYTOKINE, ADHESION MOLECULES, CHEMOKINE AND THEIR RECEPTORS IN THE SKIN AND LYMPH NODES OF TICK-INFESTED MICE}

\author{
Passoni CE, Franzin AM, Cardoso CRB, Garlet GP, Silva JS \& Ferreira BR \\ Departamento de Bioquímica e Imunologia, Faculdade de Medicina de Ribeirão Preto - USP \\ claupassoni@rpm.fmrp.usp.br
}

Ticks are haematophagous arthropods known to induce deleterious effects on their hosts, which are caused by attachment and feeding added to its capacity of transmitting important medical and veterinary pathogens. During the feeding process, they stimulate the immune and inflammatory host responses meanwhile suppress elements of natural and acquired immunity by factors present in the inoculated saliva. Mice, as dogs (natural host), do not develop resistance to ticks $R$. sanguineus, not even after successive infestations. Studies involving the role of cytokine modulation during tick infestations show that ticks induce a pattern of Th2 type response on susceptible hosts. Based on the idea that the initial decision concerning which type of T effector cell will be induced is critical to the outcome of an infection, in the present study, we aim to characterize the dynamics of cellular infiltration and the kinetics of the production of cytokines, adhesion molecules, chemokines and their receptors in the skin and lymph nodes of tick-infested mice. For such, BALB/c mice will be once and three times infested with ticks. 24 hours, 3 and 6 days post-tick attachment, the skin and lymph nodes will be collected for determination of gene expression of cytokines, adhesion molecules, chemokines and their receptors by RT-PCR. The identification and localization of the proteins which genes expression were up-regulated by tick infestation will be confirmed by immunohistochemistry. The results will contribute to better understand the tickhost relationship as well aid to development of alternative forms to ticks control.

Keywords: Ticks. Saliva. Cytokine.

Supported by: FAPESP, CNPq

\section{TICK SALIVA MODULATES THE IMMUNE RESPONSE: STUDY OF THE INVOLVEMENT OF REGULATORY CELLS}

\author{
Moré DD, Cavassani KA, Campanelli AP, Silva JS \& Ferreira BR \\ Departamento de Bioquímica e Imunologia, Faculdade de Medicina de Ribeirão Preto - USP \\ ddmore@rpm.fmrp.usp.br
}

Several studies have been performed to understand the immune mechanisms involved in tick-host interaction due to its importance in human and veterinary medicine. This led to the concept that ticks can modulate immune response by inoculation of its saliva in the host. Previous works have demonstrated that mice, as well as dogs, do not develop resistence to Rhipicephalus sanguineus ticks, not even after repeated infestations, and that tick saliva inhibits murine T cell proliferation and induces a Th2 cytokine profile. In the present study, we suggest that tick saliva modulates mice immune response by stimulating or recruiting regulatory T cells (Tregs) to the feeding site. For that, mice will be tick-infested or inoculated with saliva, and at different times (24, 48 and $72 \mathrm{~h}$ ) after stimulus, the cutaneous feeding / inoculation site will be collected and processed for identification of Tregs by flow cytometry. The characterization of the Treg phenotype will be done by staining of $\mathrm{CD}^{+} / \mathrm{CD}^{+} /$ CD $25^{+} / \mathrm{CTLA}^{+} 4^{+} / \mathrm{CD}_{4} \mathrm{RB}^{\text {low }} / \mathrm{GITR}^{+}$molecules and intracellular IL-10 e TGF- $\beta$. To determine the function of Tregs, CD25+ $\mathrm{T}$ cells will be separated with magnetic beads, expanded in vitro and tested in supression assays against naive CD4 T cells previously stimulated with Con-A. Data obtained will enhance the knowledge about saliva immunomodulatory effect and help the elucidation of Tregs suppressive mechanisms.

Keywords: Ticks. Saliva. Tregs.

Financial support: FAPESP, CNPq 


\title{
THE SALIVARY GLANDS EXTRACT OF LUTZOMYIA LONGIPALPIS VECTOR INHIBITS THE NEUTROPHIL MIGRATION INDUCED BY PERITONEAL CELLS OBTAINED FROM OVA-IMMUNIZED MICE OR THEIR SUPERNATANTS AFTER TRANSFERENCE TO NAIVE MICE
}

\author{
Monteiro MC, Romão $\mathrm{PRT}^{1}$, Souza $\mathrm{A}^{2}$ \& Cunha $\mathrm{FQ}^{3}$ \\ Departamento de Biologia, Universidade Estadual do Centro-Oeste - Guarapuava/PR, ${ }^{1}$ Universidade do Sul de Santa Catarina - \\ UNISUL - Tubarão/SC, ${ }^{2}$ Departamento de Parasitologia, Instituto Evandro Chagas - Belém/PA, ${ }^{3}$ Laboratório Inflamação, \\ Departamento de Farmacologia, Faculdade de Medicina de Ribeirão Preto - USP \\ martaachagas@hotmail.com
}

In previous works, we observed that pretreatment with salivary glands extract (SGE) of Lutzomyia longipalpis vector inhibited the neutrophil migration and TNF $\alpha$, IL- $1 \beta$ and $\mathrm{LTB}_{4}$ production induced by ovalbumin ( OVA ) in immunized mice. However, the pretreatment of mice with SGE increased the anti-inflammatory cytokines production a s IL-10 and IL-4 . In the present work, we investigated whether in vitro OVA - stimulated peritoneal cells pretreated with SGE or PBS or their supernatants were able to release pro-inflammatory mediators and also if it induces neutrophil migration when transferred to naive mice pretreated with PBS or SGE. Thus peritoneal cell suspension of OVA-immunized animals treated or not with SGE, were stimulated or not with OVA $\left(10 \mu \mathrm{g} \mathrm{ml}^{-1}\right)$ during $1 \mathrm{~h}$. Following, the cells were washed or incubated for $6 \mathrm{~h}$ and then $\mathrm{i}$.p. injected in naive mice pretreated with PBS or SGE ( cells: $1 \times 10^{5}$ cells/cav, supernatant: $0.5 \mathrm{ml} / \mathrm{cav}$ ). The neutroph IL migration was evaluated $4 \mathrm{~h}$ after stimuli injection and the TNF- $\alpha$, MIP- $1 \alpha, \mathrm{LTB}_{4}$, IL-10 and IL-4 concentration in the supernatants was determined by ELISA. The stimulation of peritoneal cells from immunized mice with OVA induced significant production of TNF- $\alpha$, MIP- $1 \alpha$ and LTB $_{4}$ (TNF- $\alpha$ : $150 \pm 20 \mathrm{pg} / \mathrm{ml}$ versus $40 \pm 10$ by control cells, MIP-1 $\alpha$ : $160 \pm 10$ versus $60 \pm 2$ and $\mathrm{LTB}_{4} 500 \pm 1$ versus $10 \pm 1$ ). However, these peritoneal cells did not release neither IL-4 nor IL-10. Furthermore, the transference of supernatant or peritoneal cells stimulated with OVA (obtained from OVA - immunized and SGE-treated animals) to naive mice induced the neutrophil migration into peritoneal cavity (supernatants: $3.75 \pm 0.25$, cells: $2.0 \pm 0.12 \times 10^{6}$ neut /cav) when compared to control groups (supernatants: $1.75 \pm 0.25$, cells: $0.5 \pm 0.15 \times 10^{6}$ neut / cav ). However, this effect was inhibited when the naive animals were pretreated with the SGE (supernatants: $1.75 \pm 0.20$, cells: $1.0 \pm 0.15 \times 10^{6} \mathrm{neut} / \mathrm{cav}$ ).

Keywords: Lutzomyia longipalpis. Salivary Glands Extract. Neutroph IL Migration .

Financial support: CNPq, FAPESP

\section{IDENTIFICATION OF A. LUMBRICOIDESTROPOMYOSIN AS AN IMPORTANT IGE BINDING PROTEIN}

\author{
Santos $\mathrm{ABR}^{1}$, Sales VSF${ }^{2}$, Dantas VCR ${ }^{2}$, Rodrigues $\mathrm{CEFB}^{2}$, Ferriani VPL ${ }^{1}$, Esch $\mathrm{RE}^{3}$, Chapman $\mathrm{MD}^{3}$ \& Arruda $\mathrm{LK}^{1}$ \\ ${ }^{1}$ Department of Pediatrics, School of Medicine of Ribeirão Preto-University of São Paulo, Brazil, ${ }^{2}$ Department of Immunology, \\ Federal University of Rio Grande do Norte, Brazil, ${ }^{3}$ Greer Laboratories, Lenoir, NC, USA, \\ ${ }^{4}$ Indoor Biotechnologies, Inc, Charlottesville, VA, USA
}

The aims of the present study were to determine the sequence of A. lumbricoides tropomyosin, and to investigate IgE antibody responses to tropomyosins from Ascaris and cockroach in children from a parasiteendemic area.Amplification of the complete cDNA encoding A. lumbricoides tropomyosin was carried out by RT-PCR, using primers syntetized on the basis of the sequences of cockroach and Anisakis simplex tropomyosin. The sequence of the 284 amino acid protein from A. lumbricoides showed $90 \%$ to $98 \%$ identity to tropomyosins from other parasites, including Anisakis simplex, and 74\% and 69\% identity to mite and cockroach tropomyosins, respectively. IgE antibodies to tropomyosins from A. lumbricoides and cockroach were quantitated by chimeric ELISA in sera of 146 preschool children. IgE to tropomyosin was found in 77/146 (52.7\%) children, and there was a significant correlation of levels of IgE to A. lumbricoides and P. americana tropomyosin ( $\mathrm{r}$ $=0.8, \mathrm{p}<0.0001$ ). Total IgE levels were significantly higher in the group with IgE to tropomyosin as compared to the group with no IgE to tropomyosin (GM: 904 and $409 \mathrm{IU} / \mathrm{mL}, \mathrm{p}=0.006)$. Our results support the hypothesis that tropomyosin may be an important protein involved in cross-reactivity among invertebrates. Further studies of the immune response to conserved molecules, including tropomyosin, will be necessary to determine the clinical relevance of these findings and establish the role of tropomyosin in the pathogenesis of asthma and rhinitis.

Keywords: Tropomyosin. Cockroach.Ascaris. Lumbricoides.

Supported by: FAPESP, CNPq 


\title{
ADOPTIVE TRANSFER OF IMMUNITY AS A PROTECTION STRATEGY AGAINST DENGUE-2 VIRUS INFECTIONS
}

\author{
Aquino MTP ${ }^{1}$, Cavassani KA², Gomes-Ruiz AC ${ }^{1}$, Silva $\mathrm{JS}^{2}$ \& Fonseca BAL ${ }^{1}$ \\ ${ }^{1}$ Departamento de Clínica Médica, ${ }^{2}$ Departamento de Bioquímica e Imunologia, \\ Faculdade de Medicina de Ribeirão Preto - USP, SP, Brasil. \\ teresaaq@rpm.fmrp.usp.br
}

Dengue is a great concern to the public health of the tropical and subtropical areas of the world. It's caused by dengue virus and it is responsible for high rates of morbidity and mortality. The development of vaccines is very important as a way to minimize the health implications caused by dengue virus. Adoptive transfer is a cellular transference from a immune donnor to a receptor genetically identical. This mechanism has been used successfully in cancer therapies, in prophylaxis and treatment to viral infections. As a potential immunization strategy, it was choosen to investigate its application with dengue-2 virus. Naive spleen cells were primed in vitro by inactivated dengue-2 virus and then transfered to naive isogenic BALB/c mice by intravenous route. The humoral immune response and protective results in isogenic BALB/c mice were analysed after the transference of primed in vitro or not primed by dengue- 2 spleen cells. After the transference of spleen cells, only animals that have received primed ones were capable in producing neutralizing antibodies. After of the intracerebral challenge with a letal dose of wild dengue-2 virus, unimmunized group became gravelly ill or died, whereas immunized groups were healthy and asymptomatic. After challenge, neutralizing antibodies and IFN- $\gamma$ ( were also detected in immunized groups, indicating the development of a protective immune response. These results sugere that adoptive transfer of immunity is a promising immunization strategy against dengue virus.

Keywords: Adoptive Tranfer. Neutralizing Antibodies. Dengue Virus.

Apoio Financeiro: FAPESP, CAPES

\section{DEVELOPMENT OF MULTIPLEX PCR AND MULTIPLEX RT-PCR FOR DIAGNOSIS OF VIRAL MENINGOENCEPHALITIS}

\author{
Mendoza LP, Aquino VH, Cunha AA, Takayanagui O \& Figueiredo LTM \\ Unidade Multidepartamental de Pesquisa em Virologia, Faculdade de Medicina de Ribeirão Preto - USP \\ lauramt@rpm.fmrp.usp.br
}

Meningoencephalitis are severe diseases that occur mainly in children, and aged adults. This disease can be caused for a broad variety of organism such as virus, bacteria, fungi and parasites. The viral causatives of meningoencephalites include enterovirus, herpesvirus, paramyxovirus, rhabdovirus, and arbovirus. In a investigation carried out in The General Hospital of the School of Medicine of Ribeirão Preto (HCFMRP), between 1998-2002, 364 probable cases of viral meningoencephalitis, showing that it is a common disease and that it is important to develop methods for specific diagnosis of these viruses. The polimerase chain reaction is a fast, sensible and specific method and it has been chosen for diagnosis of meningoencephalitis in CFS (cerebrospinal fluid) of patients followed in the HCFMRP. Here we report the preliminary results obtained with a multiplex oneround PCR assay for single-tube amplification of herpesvirus using specific primers for HSV-1, HSV-2, VZV, CMV and EBV, testing CFS from patients with clinical diagnosis of viral meningoencephalitis. Twenty five tested CFS samples allowed detection of virus genome in seven, two of them were CMV and five HSV-1.

Keyword: Virus. Meningoencephalitis. Multiplex PCR

Support: FAPESP 


\title{
SEROEPIDEMIOLOGIC STUDY OF HUMAN HERPESVIRUS 8 AND GENOTYPIC ANALYSIS OF THE CIRCU- LATING SUBTYPES OF RIBEIRAO PRETO, SP
}

\author{
Machado PRL \& Fonseca BAL \\ Departamento de Imunologia Básica e Aplicada, Área de Concentração Bioagentes Patogênicos, Faculdade de Medicina de Ribeirão Preto \\ paula@rpm.fmrp.usp.br
}

With the advent of AIDS occurred the emergency and reemergency of other infectious agents, being one of them the Human Herpesvirus 8 (HHV-8), a new oncovirus whose sequence of DNA has been demonstrated in all presentations of Kaposi's sarcoma. The distribution of the molecular subtypes is not completely understood in all geographical areas of the world. The aim of this work is the determination of the seroprevalency of HHV-8 infection in HIV-positive patients, with and without manifestations of the Kaposi's sarcoma, and in their respective familes, standardization of the Polymerase chain reaction (PCR) technique for detection of HHV8 genome, as well as the genotypic analysis of the circulating subtypes of HHV-8 in Ribeirão Preto. The patients to be included in the project are assisted in the Hospital das Clinicas da Faculdade de Medicina de Ribeirão Preto, and it will be included patients with diagnosis of AIDS with or without Kaposi's sarcoma*. The detection of antibodies anti-HHV-8 will be done by the indirect immunofluorescent assay (IFA) (Biotrin). The extraction of the DNA will be done by the QIAamp ${ }^{\circledR}$ DNA Mini Kit, PCR will be accomplished using Kit SuperMix and primers designed to amplify the region of the ORF-K1 (870pb). The "amplicons" obtained with the PCR will be sequenced in an ABI Prism ${ }^{\circledR} 310$ Genetic Analyzer using the Big Dye ${ }^{\mathrm{TM}}$ Terminator Cycle Sequencing Kit. Preliminary Results: The use of the immunofluorescence test showed the prevalence of HHV8 in $30(71,4 \%)$ of 42 patients with HIV.

* Furthermore, the relatives of these patient ones will be studied.

Keywords: HHV-8. Transmission. Genotypic Analysis.

Support: CNPq

\section{CYTOMEGALOVIRUS DETECTION IN BIOPSIES FROM PATIENTS WITH IDIOPATHIC ULCERATIVE COLITIS AND COLORECTAL CANCER}

\author{
Mariguela VC, Cunha AA, Chachá SGF, Troncon LEA \& Figueiredo LTM \\ Unidade Multidepartamental de Pesquisa em Virologia, Faculdade de Medicina de Ribeirão Preto- USP \\ Ribeirão Preto, SP, 14049-900. vivibio@ rpm.fmrp.usp.br
}

Cytomegalovirus (CMV) is a genus in the $\alpha$-Herpesvirinae subfamily of the Herpesviridae. CMV, the largest viruses of the family, are commom causatives of active infection and disease among immunodeficient patients leading to a high morbidity and case fatality. The CMV structure includes a double-stranded DNA genome of $240 \mathrm{~kb}$ inside of a icosahedral capsid surrounded by a proteic matrix and a lipidic bilayer envelope. Some gastrointestinal syndromes have been associated with CMV infection. In the last years, idiopathic ulcerative colitis (RCU), a chronic illness of inflammatory nature and unknown etiology, have been associated with CMV intestinal infection and it is possible that gene products of human cytomegalovirus can promote mutagenesis, cell-cycle progression, angiogenesis, cell invasion, and evasion immune. These are cellular pathways relevant to colorectal adenocarcinoma pathogenesis. The objective of this work is to detect the CMV genome by PCR in the intestinal mucosa of RCU and colorectal cancer patients. Intestinal biopsies of 18 idiopathic ulcerative colitis patients and of 9 negative controls having non-inflamatory intestinal diseases were submited to a PCR using primers that amplify part of the gB gene (nucleotides 1319 to 1604) and produce a 296bp amplicon. Eight of the RCU patients $(44,4 \%)$ and 2 of the negative controls $(25 \%)$ had CMV genome detected in the biopsies. The higher presence of CMV infection among idiopathic ulcerative colitis patients was not significant (.247, p.0.5). This is a following study and increasing the sample size could make significantly higher the presence of CMV infection among idiopathic ulcerative colitis patients. The colorectal cancer biopsies of fourteen patients will also be submitted to the PCR for CMV detection.

Keywords: Cytomegalovirus. RCU. Colorectal Cancer Financial. 


\title{
VaPA PROTEIN EXPRESSION OF RHODOCOCCUS EQUI IN VACCINAL STRAINS OF SALMONELLA ENTERICA
}

\author{
Oliveira $\mathrm{AF}^{1}$, Ferraz LC ${ }^{1}$, Brocchi M \& Roque-Barreira MC \\ ${ }^{1}$ Department of Cellular and Molecular Biology. School of Medicine of Ribeirão Preto. E-mail: aline@ @rpm.fmrp.usp.br
}

The serious pneumonia that affects foals and immunocompromised humans, caused by Rhodococcus equi, constitutes an important economic problem and public health, generating the interest in the development of efficient vaccines against the bacteria. There are evidences that the protein VapA of $R$. equi corresponds to an important virulence factor, and it stimulated us to evaluate its immunogenicity and protecting properties. Thus, initially the gene vapA was amplified by PCR, cloned in the vector pGEM-T and electroporated in E. coli DH5 $\alpha$. Subsequently, the gene vapA was subcloned in the plasmid pYA3137trc, electroporated in Salmonella enterica sorovar Typhimurium $\chi 4217$ and transferred by transdution to $S$. enterica $\chi 3987$. In the second stage, it was verified that the promoter trc was able to induce the constituent expression of the protein VapA. In a third stage, we noticed that both $S$. enterica $\chi 3987 \mathrm{vapA}^{+}$and S. enterica $\chi 3987 \mathrm{vapA}^{-}$strains were able to colonize and to persist in internal organs of BALB/c mice. The recombinant strains were used to immunize mice orally, and then mice were later challenged with the virulent strain of $R$. equi. Preliminar results indicated that mice immunized with the $v a p A^{+}$strains were protected against $R$. equi infection. So, our objectives are: 1) to analyze the histological sections of the organs of immunized mice and later challenged with $R$. equi, 2) to evaluate the pattern of a developed immune response, through the antibodies titer and cytokine production.

Keyword: Rhodococcus Equi / Salmonella enterica Typhimurium / Vaccines.

\author{
Poster Session 3 \\ Chairs: Prof.Dr. Ademilson Panunto Castelo and Prof.Dr. Victor Hugo Aquino Quintana
}

\section{PARTICIPATION OF PROSTAGLANDINS AND LEUKOTRIENES IN EXPERIMENTAL TUBERCULOSIS}

\author{
${ }^{1}$ Matias Peres C, ${ }^{2}$ Paula L, ${ }^{2}$ Medeiros AI, ${ }^{1}$ Carlos D, ${ }^{1}$ Frantz FG, ${ }^{1}$ Silva CL \& ${ }^{2}$ Faccioli LH \\ ${ }^{1}$ Departamento de Bioquímica e Imunologia, Faculdade de Medicina de Ribeirão Preto, ${ }^{2}$ Departamento de Análises Clínicas, \\ Toxicológicas e Bromatológicas, Faculdade de Ciências Farmacêuticas de Ribeirão Preto - USP. E-mail: peres@ @cfrp.usp.br.
}

Introduction: In this study, we evaluated the role of prostaglandins and leukotrienes in modulation of immune response during acute and chronic infection by Mycobacterium tuberculosis (Mtb). Material and Methods: BALB/c mice were infected by intratracheal route with $1 \times 10^{5}$ bacillus of Mtb and treated daily with celecoxib (5mg/kg/p.o.) and/or MK 886 (5 mg/kg/p.o.) during 60 days post infection. Results: Prostaglandins play a role in the neutrophils recruitment, during both the acute and chronic phases of infection by $M$. tuberculosis, by mechanism dependent of cytokines synthesis such as TNF $\alpha$, IL-1 and IL-6, respectively. Moreover, the Mtb-infected mice treated with celecoxib, inhibitor of prostaglandins synthesis, released more IFN- $\gamma$, IL-12 and less IL-10, when compared with infected animals without treatment. Futhermore, the role of prostaglandins in the pathogenesis of tuberculosis was confirmed, inasmuch as less CFU was recuperated in the lungs of these animals. Although the treatment of the infected animals with MK 886 inhibited the neutrophils cells recruitment only at $2^{\text {nd }}$ after infection, the results obtained in this study show that the inhibition of leukotrienes resulted in reduced survival and in the synthesis of immune cytokines such as IFN- $\gamma$ and IL-12 and in increase of CFU in the lungs of the animals. The treatment of infected animals with celecoxib + MK 886 reduced neutrophils recruitment and release of cytokines such as IL-12 and IFN- $\gamma$, and increased CFU in the lungs. Conclusion: Leukotrienes play an essential role in the protection against Mtb and the relation between these mediators released by pulmonary cells is fundamental to the protective immune response.

Keywords: Tuberculosis, prostaglandins, leukotrienesFinancial

Support: FAPESP, CNPq e FAEPA. 


\title{
EVALUATION OF THE ROLE OF MAST CELLS IN THE IMMUNE RESPONSE IN MURINE EXPERIMENTAL TUBERCULOSIS
}

\author{
Carlos D, Silva CL \& Faccioli LH \\ Departamento de Bioquímica e Imunologia, Faculdade de Medicina de Ribeirão Preto - USP \\ danicar@rpm.fmrp.usp.br
}

Tuberculosis is a pulmonary disease characterized by acute inflammatory reaction followed of a chronic phase with predominance of granulomatous lesions. Despite decades of research on chemotherapy for the disease and development of preventive vaccines, it remains a major public-health problem on the underdeveloped countries. The features of cellular immunity of the host determine the degree of clinical manifestations, inasmuch the primary effector cells implicated in the control in tuberculosis have been $\mathrm{T}$ lymphocytes and macrophages. However, other cell types, such as dendritic cells, endothelial cells and more recently mast cells seem be involved in the immunological control of Micobacterium tuberculosis in the lung. Mast cells are inflammatory cells typically found in the mucosa of the respiratory, gastrointestinal and urinary tracts. Since these sites are also common portals of infection, mast cells are likely to be one of the first cells to make contact with invading pathogens and, following activation, release a myriad of proinflammatory mediators, that are crucial for recruiting various other inflammatory cells to the site of infection. Histamine, which is a principal component of mast cell granules, mediates mainly a variety of effects in allergic inflammation, such as vasodilatation, bronchial smooth muscle contraction and increased vascular permeability. Furthermore, any recent observations have reported that this mediator performs an important role in the modulation of the cytokine network involved in the innate as well as the adaptative immune responses through of the regulation Th1/Th2 cytokine balance. Nonetheless, no studies concerning either the participation of mast cells or their mediators as histamine in the immune response in tuberculosis have yet been carried out.

Keywords: M. tuberculosis. Mast Cells. Histamine.

Financial Support: FAPESP

DEVELOPMENT OF EXPERIMENTAL VACCINE BASED ON SECRETED PROTEINS BY Mycobacterium tuberculosis PLUS CPG OLIGODEOXYNUCLEOTIDES

\author{
Fonseca DM, Silva CL, Bonato VLD \\ Rede TB - Biochemistry and Immunology Department, Faculdade de Medicina de Ribeirão Preto, USP, Brazil. \\ denise@cpt.fmrp.usp.br
}

Many vaccines against tuberculosis (TB) have been tested due to the controversy efficacy of BCG. An improved vaccine against Mycobacterium tuberculosis must induce a protective cellular immune response characterized by macrophages activation, recruitment of $\mathrm{CD}^{+}$and $\mathrm{CD} 8^{+} \mathrm{T}$ cells, and production of IFN- $\gamma$, IL12 and TNF- $\alpha$. A DNA vaccine based on the gene that codifies a protein of $65 \mathrm{kDa}$ (hsp65) of M. leprae presented a prophylactic and therapeutic effect in an experimental model of TB. Despite the promising results, this vaccine is based on a unique antigen and its efficacy may be compromised due to the heterogenity of MHC molecules. With this in mind, our aim is to test a new strategy for the development of a TB vaccine. Mice will be immunized with a suspension of secreted proteins by $M$. tuberculosis plus $\mathrm{CpG}$ oligodeoxynucleotides as adjuvant. Activation of cellular and humoral immune response will be evaluated, respectively, by detection of IL-12, IFN- $\gamma$, IL-5 and IL-10 levels in the spleen cells cultures and IgG1 and IgG2a levels in the serum. Mice will be challenged with $M$. tuberculosis by intratracheal route and the protection will be analyzed by CFU counts, detection of cytokines and memory phenotype in the lungs of immunized and infected mice, in relation to nonimmunized and infected mice.

Keywords: Vaccine. Secreted Proteins by M. tuberculosis. CpG Oligodeoxynucleotides.

Financial support: FAPESP 


\title{
EVALUATION OF IMMUNE RESPONSE AND PROTECTION AGAINST TUBERCULOSIS USING DNA-hsp65 VACCINE DELIVERY BY LIPOSOMES
}

\author{
Rosada RS ${ }^{1}$, Gaziola-de la Torre L ${ }^{2}$, Brandão IT $^{1}$, Masson $\mathrm{AP}^{1}$, Silva CL $\mathrm{CL}^{1}$, \\ Santana MHA ${ }^{2}$ \& Coelho-Castelo AAM $^{1}$
}

${ }^{1}$ Rede TB - Centro de Pesquisa em Tuberculose, Departamento de Bioquímica e Imunologia, Faculdade de Medicina de Ribeirão Preto - USP, ${ }^{2}$ Departamento de Processos Biotecnológicos, Faculdade de Engenharia Química - UNICAMP

rosada@cpt.fmrp.usp.br

Tuberculosis remains a threat for public health, killing three million people a year. The currently available means for vaccination against tuberculosis are inadequate: the highly variable level of protection induced by the commonly used vaccine bacillus Calmette-Guérin (BCG) combined with the HIV pandemic and the increasing multidrug-resistance of Mycobacterium tuberculosis strains are stressing the need for new and more effective vaccines. Previous studies from our laboratory have focused on intramuscular delivery of naked plasmid DNA encoding M. leprae 65-Kd heat shock protein (DNA-hsp65). We observed that this form of plasmid administration results in good immune induction, as well as protection against virulent $M$. tuberculosis challenge ${ }^{i}$. However, to clinical approach, improvement of DNA-hsp65 vaccine is necessary, such as dose reduction, which could be reached through carriers like liposomes. The plasmids encapsulated into liposomes are protected against nucleases action that allows a remarkably dose reduction of required DNA. Furthermore, the liposomes can be constructed in a way that exhibits different kinetics of plasmid DNA delivery, as well as a better uptake process by cells maintaining the immune response activation. Thus, the objective of this work will be evaluating the protective effectors of three different liposomes structures carrying the DNA-hsp65 by intramuscular immunization. ${ }^{i}$ Lowrie, DB et al., Nature 1999.

Keywords: Liposomes. DNA-hsp65 Vaccine. Tuberculosis.

.Supported by: FAPESP and CNPq.

\section{ROLE OF $\beta_{2}$-INTEGRIN IN PULMONARY HISTOPLASMOSIS}

\section{Turato $\mathrm{WM}^{1}$, Medeiros $\mathrm{AI}^{1}$, Frantz $\mathrm{FG}^{1}$, Silva $\mathrm{CL}^{2}$ \& Faccioli $\mathrm{LH}^{1}$}

${ }^{1}$ Departamento de Análises Clínicas, Toxicológicas e Bromatológicas, Faculdade de Ciências Farmacêuticas de Ribeirão Preto - USP ${ }^{2}$ Rede TB - Centro de Pesquisa em Tuberculose, Faculdade de Medicina de Ribeirão Preto - USP turato@rpm.fmrp.usp.br.

Histoplasma capsulatum is a dimorphic fungus, pathogenic, non obligate intracellular parasite of wide distribution for the world. $\beta_{2}$-integrins participates in leukocytes migration in differents experimental models and H. capsulatum uses this molecule to penetrate in phagocytes. In the present study we evaluated the role of $\beta_{2}-$ integrin in cell recruitment to the broncoalveolar space and in the protection against $H$. capsulatum. We demonstrate that a mutant strain for $\beta_{2}$-integrin ( $\beta_{2}$-mut) and wild-type (WT) C57BL/6 mice survive when infected with a sublethal dose $\left(5 \times 10^{5}\right.$ yeast cells). However, $\mathrm{Hc}$-infected $\beta_{2}$-mut mice exhibited increase neutrophil numbers in the BAL during the course of infection when compared to $H c$-infected WT mice. $2 \mathrm{~d}$ : WT $H c=0.47$ $\pm 0.07, \beta_{2}$-mut $H c=2.26 \pm 0.41,7 \mathrm{~d}:$ WT Hc$=0.28 \pm 0.39, \beta_{2}$-mut $H c=0.73 \pm 0.09,14 \mathrm{~d}:$ WT Hc= $1.01 \pm 0.16$, $\beta_{2}$-mut $H c=1.44 \pm 0.10 \times 10^{6} / \mathrm{mL}$. No such neutrophil migration occurred in the control group. The recovery of UFC at lungs was $1.4 \log _{10}$ less than at $\beta_{2}$-mut mice until 7 days and equivalent at 14 days when compared to $H c$-infected WT. Moreover, lung cells from Hc-infected $\beta_{2}$-mut mice generated more NO2- that lung cells from Hc-infected WT mice at 7 days (WT Hc: $23.93 \pm 1.48 \mu \mathrm{M}, \beta_{2}$-mut Hc: $37.27 \pm 3.36 \mu \mathrm{M}, \mathrm{p}<0,05$ ). No differences between the two groups in production of $\mathrm{NO}^{-}$were apparent at 14 days post-infection. These results suggest that the neutrophil recruitment to the BAL is independenty of the $\beta_{2}$-integrin and that molecule may be important in the protection in murine model of pulmonary histoplamosis.

Keywords: Histoplasma capsulatum, adhesion molecules, integrinsFinancial

Support: CNPq, FAPESP 
THE ROLE OF ICAM-1 IN THE MODULATION OF IMMUNE RESPONSE IN MICE INFECTED WITH Paracoccidioides brasiliensis

\author{
Moreira AP ${ }^{1}$, Campanelli AP ${ }^{3}$, Cavasani KA ${ }^{1}$, Milanesi $\mathrm{C}^{1}$, Dias $\mathrm{ARV}^{1}$, Martinez R ${ }^{1}$, Rossi MA² \& Silva JS ${ }^{1}$ \\ ${ }^{1}$ Department of Biochemistry and Immunology, Departament of Pathology, ${ }^{2}$ Department of Internal Medicine. Ribeirão Preto, \\ University of São Paulo, Brazil. ${ }^{3}$ Department of Biological Science. School of Dentistry of Bauru - University of São Paulo, Brazil. \\ apmoreira@rpm.fmrp.usp.br
}

The cellular immune response raised against Paracoccidioides brasiliensis plays an important role in the defense against the fungus, since it contributes to the killing of the yeast cells. In this study, we investigated the role of adhesion molecules ICAM-1 in the recruitment of inflammatory cells to the lungs of mice infected with $P$. brasiliensis and the involvement of this molecule on the resistance against this deep mycosis. The absence of ICAM-1 results in more susceptibility to the infection, with higher mortality rates than the observed in WT mice. We found absence of well-defined granulomas in infected-ICAM-1KO mice until 60 days of infection, period in which there was increased fungus growth in the lungs, spleen and liver compared with infected WT mice. The enhance fungus growth was associated with a impaired migration of CD4 ${ }^{+}$and $\mathrm{CD} 8^{+} \mathrm{T}$ lymphocytes migration to the inflammatory sites. After the 60 days of infection we observed a well-defined granuloma formation, decreased amount of viable fungus in the lesions and absence of mortality. Altogether, this results suggest that the expression of ICAM-1 plays a crucial role in the early T lymphocytes recruitment to the site of infection with $P$. brasiliensis. This T cell migration results in compact granuloma formation and in the resistance to the infection.

Keywords: Paracoccidioidomycosis. Granuloma. Cellular Migration.

Supported by FAPESP.

SPLENIC CELLS RESPONSE TO PARACOCCIN STIMULUS OF MALE AND FEMALE MICE INFECTED WITH Paracoccidioides brasiliensis

\author{
Pinzan CF, Casabona-Fortunato AS \& Roque-Barreira MC \\ Department of Cellular and Molecular Biology. School of Medicine of Ribeirão Preto - University of São Paulo \\ mila@rpm.fmrp.usp.br
}

Paracoccidioidomycosis is a deep mycosis in Latin America. The causative agent is Paracoccidioides brasiliensis, a thermal dimorphic fungus. One of the most intriguing characteristics of paracoccidioidomycosis is its unequal gender distribution, with males more frequently manifesting clinical disease than females in a ratio of about 15:1. These data suggest that hormonal factors play a critical role in the pathogenesis of the disease. We have shown that $P$. brasiliensis yeasts release paracoccin, a GlcNAc biding protein. In the present work we will focus on the paracoccin effect on cytokine production by cells obtained from the spleen of male and females C57B1/6 mice infected with $P$. brasiliensis. Preliminaries comments carried with adherent cells obtained from the peritoneal cavity of uninfected mice, of both sex, had shown that, front of the stimulus with paracoccin, cells proceeding from females had produced higher concentrations of IFN- $\gamma$ in comparison with cells of males, whose the production of this cytokine was lower. In the case of TNF- $\alpha$, high levels had been verified in cells of males and females, with certain advantage for females. We also verified the production of nitric oxide (NO) by adherent cells under stimulation with paracoccin $(0,25 \mathrm{mg} /$ well $)$ associated or not with IFN- $\gamma$. We verified that female cells stimulated only with paracoccin or with paracoccin addicioned with IFN- $\gamma$ yielded high levels of NO . Male cells, front to the same stimulus, had produced three times less N O than female cells. Further investigations are needed to better determine the rolls of paracoccin in the major susceptibility of male mice in the infection for P. brasiliensis.

Keywords: Paracoccidioides brasiliensis. Cytokines. Paracoccin.

Supported by CNPq 


\title{
ICAM-1 DEFICIENCY LEADS TO IMPAIRED RECRUITMENT OF T LYMPHOCYTES AND ENHANCED HOST SUSCEPTIBILITY TO INFECTION WITH Trypanosoma cruzi
}

\author{
Celes MRN ${ }^{1}$, Michailowsky V², Marino AP ${ }^{2}$, Silva AA², Vieira LQ ${ }^{3} \&$ Rossi MA ${ }^{1}$, \\ Gazzinelli RT ${ }^{3}$, Lannes-Vieira $\mathbf{J}^{2}$, Silva JS ${ }^{1}$
}

\begin{abstract}
${ }^{1}$ Departments of Biochemistry and Immunology, and Pathology, Faculty of Medicine of Ribeirão Preto, University of São Paulo, ${ }^{2}$ Department of Immunology, IOC - FIOCRUZ, ${ }^{3}$ Department of Biochemistry and Immunology, ICB - UFMG. mrubia@rpm.fmrp.usp.br
\end{abstract}

In this study we investigated the involvement of Th1 cytokines in the expression of cell adhesion molecules (CAM) and recruitment of inflammatory cells to the heart of mice infected with Trypanosoma cruzi. Our results show that endogenously produced IFN- $\gamma$ i s essential to induce optimal expression of VCAM-1 and ICAM-1 o n the cardiac vascular endothelium of infected mice. Further, the influx of inflammatory cells into the cardiac tissue was impaired in Th1 cytokine-deficient infected mice, paralleling the intensity of VCAM-1 and ICAM-1 expression on the vascular endothelium. Consistent with the importance of ICAM-1 in host resistance, ICAM-1 KO mice were highly susceptible to $T$. cruzi infection, as assessed by mortality rate, parasitemia, and heart tissue parasitism. The enhanced parasitism was associated with a decrease in numbers of $\mathrm{CD}^{+}{ }^{+}$and $\mathrm{CD} 8^{+} \mathrm{T}$ lymphocytes in the heart tissue of ICAM-1 KO mice. Additionally, ICAM-1 K O mice mounted an unimpaired IFN- $\gamma$ response, and IFN- $\gamma$-dependent production of reactive nitrogen intermediates and parasite specific IgG2a . Supporting the participation of ICAM-1 in cell migration during T. cruzi infection, the entrance of adoptively transferred peripheral blood lymphocytes from $T$. cruzi-infected wild type C57BL/6 mice into the cardiac tissue of ICAM-1 KO mice was significantly abrogated. Therefore, we favor the hypothesis that ICAM-1 plays a crucial role in $\mathrm{T}$ lymphocyte recruitment to the cardiac tissue and host susceptibility during T. cruzi infection.

Keyword : Parasitic-Protozoan. Adhesion Molecules. Inflammation.

Support by: CAPES, CNPq, FAPESP

IMPAIRED T CELL MIGRATION TO THE HEART TISSUE IN CCR5 DEFICIENT MICE INFECTED WITH Trypanosoma cruzi

\author{
Koyama NS, Campanelli AP, Rossi MA \& Silva JS \\ Department of Biochemistry and Immunology, Department of Pathology, School of Medicine of Ribeirão Preto-University of São Paulo. \\ natalia@rpm.fmrp.usp.br
}

Chagasic myocarditis is characterized by foci of myocyte necrosis and an inflammatory infiltrate composed by mononuclear cells. The role of chemokines in the triggering and modulation of cell migration into the heart remain unknown, but are certainly involved in the development and maintenance of chagasic myocarditis. Previous results revealed that CCR 5 chemokine ligands (RANTES, MIP-1 $\alpha$ and MIP-1 $\beta$ ) are produced by $T$. cruzi-infected myocardial cells both in vitro and in vivo. In this study the objective was to evaluate the role of CCR5 and their chemokine ligands in host defense against T. cruzi and in the pathogenesis of chagasic myocarditis. Thus, C57BL/6 wild type (WT) and CCR5-deficient mice $\left(\mathrm{CCR}^{-/}\right)$were infected by $T$. cruzi, and the results demonstrate that CCR5-/- mice were more susceptible to infection, presenting higher parasitemia and mortality when compared to WT mice. We investigated whether the higher mortality of CCR5-/- mice was due to defects in leukocyte recruitment into the heart, impairing the control of parasite replication. Our results showed a reduced inflammatory infiltrate and significantly higher amount of amastigote nests in the myocardium of $\mathrm{CCR}^{-1}$ mice when compared to WT mice. Analysis of cells from inflammatory infiltrate in cardiac tissue of $\mathrm{CCR}^{-/-}$mice revealed reduced number of $\mathrm{CD}^{+}{ }^{+} \mathrm{T}$ cells and macrophages when compared to WT. Our results suggest that CCR5 plays relevant role in host defense and cellular migration into the heart during $T$. cruziinfection.

Keywords: CCR5. Trypanosoma cruzi. Myocarditis.

Financial support: CAPES and CNPq. 


\title{
STUDY OF THE REPLICATION OF DENGUE-2 VIRUS UNDER THE ACTION OF INHIBITORS OF THE CELLULAR METABOLISM
}

\author{
Farias KJS \& Fonseca BAL \\ Departamento de Imunologia Básica e Aplicada - Bioagentes Patogênicos, Faculdade de Medicina de Ribeirão Preto - USP \\ kfarias2@rpm.fmrp.usp.br
}

The dengue-2 virus is a member of the family Flaviviridae. It possesses single-strand RNA genoma of positive polarity, of about $11 \mathrm{~kb}$, that encodes a single polyprotein, including three structural proteins and seven non-structural proteins. This project intend to study the effects of inhibitors of the cellular metabolism on the replication of the dengue- 2 virus in relation to the cytoskeleton, to the increase of the endosomal $\mathrm{pH}$, and the interruption of the vesicular transport of the endoplasmic reticulum to the Golgi apparatus. The methodology will use the cultivation of C6/36, HeLa and Vero cells, and the confluent monolayer of these cells will be infected with dengue-2 virus, at a multiplicity of infection (MOI) of 1 pfu per cell, to obtain the viral stock. In order to detect the viral replication, an indirect immunofluorescent assay will be done in the cellular monolayer, and extraction of total RNA of the supernatant will be performed through the QIAamp® RNA Viral Kit (QIAGEN@, USA). The detection of metabolic inhibition will be done in monolayer of Vero cells grown in 24-well plates after viral infection and treatment with Chloroquine, Cytochalasin B and Brefeldin A in pre-defined concentrations. The drugs will be in contact with the cells for pre-determined periods and collected after incubation. The action of the drugs on the endosomal acidification, cytoskeleton and vesicular transport and the consequent effect on viral replication will be analyzed through the viral titer measurements (infectivity) in cells (PRNT- neutralization tests) and by Real time PCR .

Keywords: Replication. PCR. Inhibitors.

Support: CAPES

\section{DEVELOPMENT AND PRELIMINARY EVALUATION OF A DNA RECOMBINANT VACCINE THAT EXPRESSES THE PRM AND E GENES OF THE DENGUE-3 VIRUS}

\author{
De Paula SO \& Fonseca BAL \\ Laboratório de Virologia Molecular, Departamento de Clínica Médica, Faculdade de Medicina de Ribeirão Preto - USP \\ depaula@rpm.fmrp.usp.br
}

Dengue viruses cause a wide spectrum of symptoms ranging from asymptomatic infections to a severe disease denominated dengue hemorrhagic fever/dengue shock syndrome. Researches aiming at the development of dengue vaccines have explored several aspects of vaccine production techniques, from classic methods such as the viral attenuation to expression of recombinant antigens in expression vectors, such as, viruses or bacteria. With the objective of developing a vaccine for the dengue virus, having the dengue- 3 as a prototype, the genes coding for prM and E proteins were Polymerase Chain Reaction (PCR) amplified and then inserted in an expression plasmid. After selection of the recombinant clones containing $\mathrm{prM} / \mathrm{E}$ genes, they were transfectated in HeLa cells. After the transfection, the cells and the supernatant were submitted to an immunofluoresce indirect reaction, to an immunoprecipitation and a sandwich ELISA in order to detect prM and E protein expression. Up to this the moment, 6 clones were obtained, and their biochemical analysis demonstrated that they express the prM and E proteins of dengue-3 virus. Currently, they are being tested in mice assaying for the induction of the development of specific immune response for the dengue- 3 virus.

Keywords: Dengue-3. DNA Recombinant Vaccine.

Financial support: FAPESP 


\title{
Oral Session 1
}

\author{
Chairs: Profa.Dra. Lúcia Helena Faccioli and Profa.Dra. Yara Maria Lucisano Valim
}

\section{DO X- AND Y-CHROMOSOME-BEARING BOVINE SPERMATOZOA DIFFER IN PROTEINS ON CELL SURFACE?}

Soares SG \& Barbosa JE

Departamento de Bioquímica e Imunologia, Faculdade de Medicina de Ribeirão Preto - USP. soares@rpm.fmrp.usp.br

Predetermining the sex of offspring is of interest for the prevention of transmission of X-linked diseases in humans and for increasing the rate of genetic progress in livestock. Identification of sex-specific antigens is an approach in the attempt to separate $\mathrm{X}$ and Y spermatozoa. However, conflicting results have been reported about a possible difference between $\mathrm{X}$ and $\mathrm{Y}$ spermatozoa in expressing a male-specific protein. The advent of combinatorial antibody libraries and their display on phage has provided a powerful technique not only to identify antibodies that bind to a purified antigen of interest, but also to directly select, rather than screen, for tumorspecific antibodies by panning against whole tumor cells and using normal cells for counter-selection. In our laboratory, we use the Griffin.1 library (Centre for Protein Engineering, MRC, Cambridge, UK), which consists of a large nonimmune human scFv-phage library.The phage library was panned by coating immunotubes with solubilized antigens from sperm cells. Phage-antibodies selected were used to produce soluble scFv in infected E. coli HB2151. Bacteria were picked into 96-well plates containing medium culture supplemented and expression of soluble $\mathrm{scFv}$ was induced by the addition of IPTG. Analysis of scFv for binding to sperm cells by FACS was performed on bacterial supernatants. Positive clones were re-analysed for binding to male and female leukocytes. Soluble scFvs preferential binding for male or female leukocytes were identified. Such scFv antibodies may prove to be especially useful reagents to sexing bovine offspring.

Keywords: Sexing. Phage Display. Male-specific Antigen.

This study was supported by grants from FAPESP, CAPES

\section{CONSTRUCTION AND CHARACTERIZATION OF THE DPS-NULL MUTANT OF Salmonella enterica TYPHIMURIUM}

\author{
HannaES ${ }^{1}$, Gatti KML, Bernardes ES ${ }^{2}$, Panunto-Castelo A ${ }^{2}$, Almeida IC ${ }^{3}$, Sousa MV ${ }^{4}$, Roque-Barreira MC ${ }^{2}$ \& Brocchi M \\ ${ }^{1}$ Laboratório de Bacteriologia, ${ }^{2}$ Laboratório de Imunoquímica do Departamento Biologia Celular, Molecular e Bioagente \\ Patogênicos - Faculdade de Medicina de Ribeirão Preto - USP, ${ }^{3}$ Laboratório Glicobiologia de Parasitas - Instituto de Ciências \\ Biomédicas - USP, ${ }^{4}$ Centro Brasileiro de Pesquisa em Proteínas - UnB.
}

The crystallization of cellular components represents a unique survival strategy for bacterial cells under stressed conditions. Thus, microrganisms possess a complex system of biomolecules protection in order to keep their viability even in harmful environments. A mechanism has been characterized in Escherichia coli, where monomers of a protein called Dps (DNA binding protein from starved cells) form well organized intracellular structures, in which DNA molecules are sequestered and structurally protected, in a process independent on energy consumption. In periods of starvation and/or oxidative damage, high levels of Dps are produced in the bacterial citosol and highly ordered crystalline complexes are formed to maintain the integrity of the microrganism. An $18 \mathrm{kDa}$ protein, purified from the crude extract of Salmonella enterica Typhimurium (st), with $100 \%$ homology with Dps, was isolated and characterised by its jacalin-binding ability. ESI-MS analysis with native and deglycosylated proteins indicated that a small oligosaccharide (449 Da) must be associated with the stDps molecule. Furthermore, GC-MS analysis showed that one residue of the stDps glycan is mannose, and that there is another residue not yet elucidated. Since glycosylation on any Dps molecule was never reported before, little is known about the functional aspects of this process, as well as the genesis and packing of these superstructures. In this way, we are now constructing the S. enterica mutant dps-null in order to assess the effect of this mutation on stDps glycosylation.

Keywords: Dps, Glycoprotein, DNA protection.

Support: CNPq, CAPES, FAPESP, FAEPA, FMRP-USP. 


\title{
PHOPQ: A FEED-BACK POSITIVE SYSTEM FOR HETEROLOGOUS ANTIGEN EXPRESSION IN ATTENUATED Salmonella enterica STRAINS
}

\author{
Brandão LG \& Brocchi M \\ Departamento de Biologia Celular e Molecular e Bioagentes Patogênicos. Faculdade de Medicina de Ribeirão Preto - USP \\ lucinda_gb@yahoo.com.br
}

Attenuated Salmonella enterica strains are used to deliver heterologous antigens for the immune system. Different kinds of systems are being developed where they are activated only in an adequate compartment of the host. In this way we investigated the potential of a system including the use of a high copy number asd plasmid (pYA3137) and the inducible promoters of genes as pagC or pagD, in the ability to express heterologous antigens. The promoters of these genes are regulated by PhoPQ proteins (membrane and citoplasmatic). The membrane protein is only activated in low concentrations of magnesium an environment found inside the macrophages. Consequently the citoplasmic protein and the pag genes are activated resulting in the expression of heterologus antigens. Previous results showed high levels of antigens expression by this system not only in the culture medium but also in cell culture. The gene reporter that is used for the purpose of checking the levels of expression is the $g f p$ that codes for the green fluorescent protein. Different fluorescent levels are determined by Fluorescence-activated Cell Sorter (FACS). In a new system the phoPQ operon is inserted in the pYA3137 plasmid upstream the pag promoters and in this way working as a feed-back loop to elevate the levels of heterologous antigens expression. The system is going to be tested using attenuated Salmonella enterica H683 and $\chi 3987$ $\Delta$ asd strains.

Keywords: PhoPQ. PagC. PagD.

\section{IDENTIFICATION OF PARTIAL cDNA ENCODING FOR NOTCH/LIN-12 AND PRESENILIN PROTEINS IN Schistosoma mansoni}

\author{
Magalhães GL, Sá GR \& Rodrigues V \\ Departamento de Bioquímica e Imunologia, Faculdade de Medicina de Ribeirão-Preto - USP \\ lizandra@rpm.fmrp.usp.br
}

S. mansoni is one of causative agents of schistosomiasis, a parasite disease that affects 306 million of people around tropical and subtropical areas of the world. During their life cycle, the parasite undergoes a complex migration and development process within the definite and intermediate hosts. It is described that the development use a small set of essential molecular signals such as: Wingless, Hedgehog, Transforming Growth Factor- $\beta$, Receptor Tyrosine Kinase/ Phosphatase and Notch pathaways (Gerhart, 1999). Preliminary analysis of a set of 30988 contigs gerated by the Genome Project of $S$. mansoni (ONSA/FAPESP), showed the presence of sequences of the Notch/LIN-12 receptors, CSL that are transcriptional cofators, Furin-like convertase, Kuzbanian, Presenilin that are proteases involved in the proteolytic process of the receptor, Numb/Sel-1 negative regulator of receptor, Fringe positive regulator of pathway, Hairless negative regulator of pathway, Groucho act as a cor-represso , Mastermind/LAG-3 are coativadors transcriptional and Supressor of Deltex/Sel-10 is E3 ubiquitin ligase. Furthermore, we performed RT-PCR to identification partial cDNA encoding for Notch/LIN-12 and Presenilin proteins. These results show the first evidence of the Notch pathway during the development of S. mansoni.

Keywords: S.mansoni. Notch/LIN-12 receptor. Presenilin. 


\title{
GENETIC SIMILARITY RELATEDNESS BETWEEN YERSINIA ENTEROCOLITICA STRAINS ISOLATED FROM HUMAN DIARRHEIC FECES, SICK ANIMALS AND FOODS USING THE ERIC-PCR TECHNIQUE
}

\author{
Falcão JP ${ }^{1}$, Falcão DP ${ }^{2} \&$ Brocchi $\mathrm{M}^{1}$ \\ ${ }^{1}$ Department of Cellular, Molecular Biology and Pathogenic Bioagents, Medical School of Ribeirão Preto, University of São Paulo -USP; \\ ${ }^{2}$ Department of Biological Sciences, Pharmaceutical Science School, University of the São Paulo State - Araraquara \\ pfrimer@rpm.fmrp.usp.br, falcaodp@fcfar.unesp.br, brocchi@fmrp.usp.br.
}

Y. enterocolitica is a human and animal pathogen which causes a variety of intestinal and extraintestinal clinical symptoms of varying severity ranging from mild gastroenteritis to mesenteric lymphadenitis, which mimics appendicitis, and septicemia. Molecular typing studies in Y. enterocolitica strains are important because they allow us to determine the genetic similarities between strains isolated from different sources. Furthermore, this type of study can sometimes elucidate questions about the epidemiology and prevalence of pathogenic clones. In this study, 37 Y. enterocolitica strains isolated from human diarrheic feces, 34 strains from sick animals and 35 strains isolated from different sources of food were genetically compared using the ERIC-PCR technique. It was found that all strains isolated from sick humans (37) and animals (34) were genetically very similar. These strains possessed the same bioserotype (4/O:3) and important virulence genes as ail and yst. The strains isolated from food showed a lower genetic relatedness within each other and presented also different bioserotypes none of them bioserotype 4/O:3. Just two of the 35 food strains presented the ail and yst virulence genes. Interestingly, these two food strains carrying important virulence genes were genetically more related to the ones isolated from sick humans and animals than to the others food strains. In this way, we can conclude that molecular typing was more efficient than traditionally bioserotyping in distinguishing pathogenic from non-pathogenic strains. We are now performing PFGE, a more accurate molecular typing technique to confirm these results.

Keywords: Y. enterocolitica. Molecular Typing. ERIC-PCR.

Financial Support: FAPESP

\section{ANALYSIS OF GENE EXPRESSION PROFILING OF Mycobacterium tuberculosis INFECTED MICE TREATED WITH TWO DISTINCT HSP65-DNA VACCINES.}

Zárate-Bladés CR ${ }^{1}$, Silveira ELV ${ }^{2}$, Paula $\mathrm{MO}^{2}$, Bonato VLD ${ }^{1}$, Coelho-Castelo AAM ${ }^{1}$, Donadi EA ${ }^{3}$, Sakamoto-Hojo ET ${ }^{4}$, Ramos $\mathrm{SG}^{5}$, Passos $\mathrm{GAS}^{2} \&$ Silva $\mathrm{CL}^{1}$

${ }^{1}$ Center of Tuberculosis Research, ${ }^{2}$ Molecular Immunogenetics Group, FMRP-USP, ${ }^{3}$ Department of Internal Medicine,

${ }^{4}$ Department of Biology, ${ }^{5}$ Department of Pathology, Medicine School of Ribeirão Preto, University of São Paulo, Brazil.

Efforts are directed to develop a new vaccine for tuberculosis (TB) since BCG has shown great variability of efficacy. Our earlier results have shown that a DNA vaccine based on the $65 \mathrm{kDa}$ heat shock protein of Mycobacterium leprae (pcDNA3-hsp65) has both, protective and therapeutic effects in a murine model of TB. To better understand the effects of this vaccine during the treatment of infected mice, we are studying the gene expression profiling of these mice using microarrays. As pcDNA3 is a vector not able for use in humans, we added to the study the pVAX1-hsp65 construction. In this context, $10 \mathrm{mg}$ of pcDNA3-hsp65 and pVAX1-hsp65 were obtained with high purity and integrity. BALB/c mice were infected with $10^{5} \mathrm{cfu}$ of $\mathrm{H} 37 \mathrm{Rv}$ strain through intra-tracheal route. At days 30, 40, 50 and 60 after infection, mice were treated with: a)PBS-sacarose $25 \%$ (PBS-SAC), or b)PBS-SAC+100 $\mu \mathrm{g}$ of pcDNA3-hsp65, or c)PBS-SAC+100 $\mu \mathrm{g}$ of pVAX1-hsp65. Endotoxinfree conditions were checked across the experiments. At days 32 and 70, samples were isolated for lung histology and cytokine production. RNA were purified from inguinal lymph nodes, spleen and lungs and used to prepare probes for microarray assays. Microarray slides were produced using 4.500 cDNA IMAGE and RZPD clones. These clones were amplified by PCR, purified, analyzed in agarose gels and spotted on T7 glass slides. After hybridizations, the bioinformatic softwares SAM and Cluster-Tree View will be used to disclose the significant differentially expressed genes identified between the distinct treatments.

Keywords: DNA Vaccines. Gene Expression. Microarrays.

Supported by: FAPESP, (00/09663-2, 02/07064-0 and 99/12135-9), REDE-TB, CNPq, CAPES, FAEPA. 


\title{
Oral Session 2
}

\author{
Chairs: Dr. Vânia Luiza Deperon Bonato and Dr. Geraldo Aleixo da Silva Passos Júnior
}

\section{TNF- $\alpha$ RELEASE IN VISCERAL LARVA MIGRANS SYNDROME IS PARTIALITY RELATED WITH IL-5 AND LEUKOTRIENES PRODUCTIONS}

\author{
Aníbal FF ${ }^{1,2}$, Malheiro $\mathrm{A}^{2}$, Machado ER ${ }^{2}$, Rogério $\mathrm{AP}^{2} \&$ Faccioli $\mathrm{LH}^{2}$ \\ ${ }^{1}$ Faculdade de Medicina de Ribeirão Preto, ${ }^{2}$ Faculdade de Ciências Farmacêuticas de Ribeirão Preto - USP
}

Introduction: Using the well established mice model of Toxacara canis $(\mathrm{Tc})$ infection, we determined the release of one relevant cytokine, TNF- $\alpha$, and studied its interaction with IL-5 and leukotrienes. In the present study we investigated whether TNF- $\alpha$ is released during Tc induced eosinophilic inflammation in mice. Since during the course of infection we observed a release of TNF- $\alpha$, we also examined the relationship between TNF- $\alpha$ release in vivo by inducing IL-5 depletion or/and leukotrienes depletion. Methods: Mice were infected with $1000 \mathrm{Tc}$ eggs and treated or not with TRFK-5 i.p., an anti-IL-5 Ab (only once-3 mg/animal) at the time of infection, or treated with MK-886, an leukotrienes inhibitor (p.o./daily $1 \mathrm{mg} / \mathrm{Kg}$ ), or both. The infected mice were killed 18 days post infection. TNF- $\alpha$ was evaluated by ELISA. Results: Tc-infected mice developed lung and blood eosinophilia. In the lung of infected mice, TNF- $\alpha$ levels increased 18 days after infection (1379 $\pm 324 \mathrm{pg} /$ $\mathrm{ml})$, Infected and treated with TRFK-5 $(800 \pm 104 \mathrm{pg} / \mathrm{ml})$, or MK-886 $(792 \pm 54 \mathrm{pg} / \mathrm{ml})$ present decrease of TNF$\alpha$ levels in the lung, but infected and treated with both present of TNF- $\alpha$ levels similar of only infected $(1410 \pm 145$ $\mathrm{pg} / \mathrm{ml})$. The group control present of TNF- $\alpha$ levels $(394 \pm 70 \mathrm{pg} / \mathrm{ml})$. Conclusions: Tc-infected mice developed systemic eosinophilia and increase in TNF- $\alpha$ release in Tc-infected mice is partiality regulated by with IL- 5 and leukotrienes.

Keywords: Eosinophilia. IL-5. Leukotrienes.

Supported by: CAPES, CNPq, FAEPA, FAPESP

\section{THE ROLE OF CYTOKINES AND CHEMOKINES IN A NEW MODEL OF INFLAMMATORY BOWEL DISEASE}

\author{
Cardoso $\mathrm{CRB}^{1}$, Teixeira GAPB ${ }^{2}$, Cunha $\mathrm{FQ}^{3} \&$ Silva $\mathrm{JS}^{1}$ \\ ${ }^{1}$ Departamento de Bioquímica e Imunologia, ${ }^{3}$ Departamento de Farmacologia, Faculdade de Medicina de Ribeirão Preto - USP \\ ${ }^{2}$ Instituto de Biologia, Universidade Federal Fluminense. cristina@ @rpm.fmrp.usp.br
}

The Inflammatory Bowel Diseases (IBD) involve the interaction of genetic susceptibility, enviromental challenges and altered mucosal immunity, and the involvement of cytokines and chemokines is crucial in disease's severity and outcome. Advances in the study of IBD has been reported in a variety of mouse models of intestinal inflammation. Accordingly, this work aimed to study a murine model of intestinal inflammation, induced by peanut seeds proteins (PSP), that resembles human IBD. Animals were imunized with PSP and then challenged with peanut ad libitum for 5, 15 or 30 days ininterruptely. The results showed that animals submitted to such protocol presented an increase in inflammatory cells infiltrate in small gut, accompanied by congestion and edema in lamina propria, that resulted in significative alterations in gut architecture. Changes in cytokine and chemokine mRNA expression were detected by RT-PCR. An apparent increase expression in TGF- $\beta$, IL-18 and IP-10 mRNA was observed in animals fed peanut seeds for 5 days and a decrease in IL-18, MIP-1 $\alpha$, and MIP- $1 \beta$ in 15 days fed animals, when compared to control. It was also noted a decrease in TNF- $\alpha$, IFN- $\gamma$, IL-10, IL18 , MIP-1 $\alpha$, MIP-1 $\beta$ and CCR2 mRNA expression in 30 days inflammed animals. Such data must yet be confirmed as mRNA's expression will be quantified by Real-Time PCR. These results indicate that animals exposure to PSP followed by challenge with peanut seeds develop intestinal inflammation characterized by an increased inflammatory infiltrate, changes in intestinal morphology and altered cytokine and chemokine expression.

Keywords: Peanut. Gut. Inflammation.

Supported by: FAPESP 


\title{
MECHANISMS INVOLVED IN THE NEUTROPHIL MIGRATION INDUCED BY METHYLATED BOVINE SERUM ALBUMIN IN IMMUNIZED MICE (MBSA)
}

\author{
Nogueira LG, Ramos CDL \& Cunha FQ \\ Laboratory of the Inflammation, Department Pharmacology, School of Medicine of Ribeirão Preto - University of São Paulo, Brazil \\ Luciana_lgn@ig.com.br
}

Introduction: Neutrophils are major cells involved in host defense against microorganism infections. Though they had a protective effect, the damage tissue observed in inflammatory disease such as rheumatoid arthritis, glomerulonephritis, immune vasculitis and inflammatory bowel disease is, at least in part, consequence of neutrophil accumulation. In this work, we investigated the mechanisms involved in the neutrophil migration in a model of immune inflammation induced by mBSA. Methods and Results: Wild type (WT), deficient IL-12 (IL-12 $2^{-/}$),

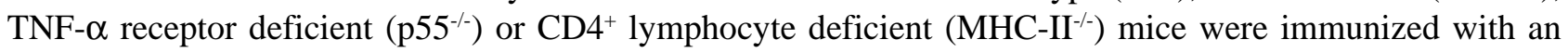
emulsion contend PBS/CFA with or without (control mice) 50mg of mBSA (i.d., $0.1 \mathrm{~mL}$ ). After 7 days of the immunization, these animals received the challenge i.p with $10 \mu \mathrm{g}$ of mBSA. The neutrophil migration was evaluated 6 hours after of the challenge injection per total and differential counts. Our results demonstrated that mBSA induced neutrophil migration in WT immunized mice. However, this fact was not observed in IL-12 $2^{-/}$,

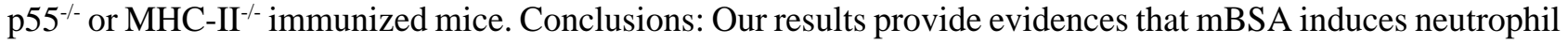
migration by mechanisms dependents of synthesis and/or release of inflammatory mediators, such as, TNF- $\alpha$ and IL-12. In addition, we observed that $\mathrm{CD} 4^{+}$lymphocytes have a pivotal role on recruitment of neutrophils in this model of immune inflammation.

Keywords: Neutrophils. Cytokines. CD4 Lymphocytes.

Supported by: CAPES, PRONEX, FAPESP

\section{THE OPPOSITE ROLES OF T HELPER RESPONSES IN THE IMMUNOPATHOGENESIS OF EXPERIMENTAL PERIODONTAL DISEASE}

\author{
Garlet GP ${ }^{1}$, Avila-Campos $\mathrm{MJ}^{2} \&$ Silva JS ${ }^{1}$ \\ ${ }^{1}$ Immunoparasitolgy Laboratory, Department of Biochemistry and Immunology, School of Medicine of Ribeirão Preto - Faculdade de \\ Medicina de Ribeirão Preto - USP; ${ }^{2}$ Anaerobe Laboratory, Department of Microbiology, Institute of Biological Sciences - USP \\ gustavo@rpm.fmrp.usp.br
}

Inflammatory immune reactions in response to periodontopathogens are thought to protect the host against infection, but may triggers periodontal destruction. In order to study these events we first examined the role of the cytokines IFN- $\gamma$, IL-4 and IL-10 on the regulation of matrix metalloproteinases (MMPs, host enzymes that degrade extracellular matrix), the osteoclastogenic factor RANKL and their respective inhibitors TIMPs and OPG in gingival biopsies of Actinobacillus actinomycetemcomitans (AA) induced PD in mice. By Real Time PCR we detected the expression of IFN- $\gamma, \operatorname{MMPs}(1,2,9)$ and RANKL during all the course of disease in C57B16(WT)mice. After 30d of infection, we detected IL-10, associated with an increase in TIMPs(1,2,3) and OPG expression, and a decrease of MMPs and RANKL. In fact, higher expression of MMPs and RANKL and lower expression of TIMPs and OPG in mice genetically deficient(KO) of IL-4 or IL-10 was associated with higher severity of PD, while a decrease in MMPs and RANKL and increase in TIMPs and OPG resulted in lower bone loss in IFN-KO mice. However, IFN-KO mice did not control the infection resulting in mice death, and positive AP-PCR reactions to AA were found in lung, liver and heart, while in WT, IL-4 and IL-10KO mice the AA detection remained restrict to the periodontal tissues. Our data suggests that IFN- $\gamma$ drives enhanced bone resorption whereas protects the host from lethal AA dissemination, while IL-4 and IL-10 does not compromise the control of infection and contributed to attenuate the tissue destruction.

Keywords: Periodontal Disease. Th1 Response. Immunomodulation.

Supported by FAPESP. 


\title{
ROLE OF IL-18 IN MURINE SYSTEMIC INFECTION BY Paracoccidioides brasiliensis
}

\author{
Panagio LA ${ }^{1}$, Campanelli $\mathrm{AP}^{2}$, Moreira $\mathrm{AP}^{1}$, Pereira $\mathrm{MSF}^{1} \&$ Silva JS ${ }^{1}$ \\ ${ }^{1}$ Department of Biochemistry and Immunology, School of Medicine of Ribeirão Preto, ${ }^{2}$ Department of Biological Sciences, \\ School of Dentistry of Bauru, University of São Paulo, Brazil. lapanagio@rpm.fmrp.usp.br
}

Paracoccidioides brasiliensis is a dimorphic fungus, causative of paracoccidioidomycosis, a systemic disorder that primarily involves the lungs and then disseminates to other organs. An elaboration of a Th1 response is mandatory for granulomata formation, an event involved in the constraining of the infection. IL-18 is cytokine with pleiotropic functions, including the stimulation of IFN- $\gamma$ production and the induction of apoptosis through CD95/CD95L pathway. In humans, apoptosis mediated by CD95/CD95L modulates the immune response in paracoccidioidomycosis. Mice genetically deficient of IL-18 (IL-18KO) or CD95 (CD95KO), and the wild-type (WT) Balb/C and C57BL/6 strain, received the intravenous inoculation with $10^{6}$ yeasts of $P$. brasiliensis, and were sacrificed 7, 15 ou 30 days after infection. IL-18KO and CD95KO mice presented a significant increase in the CFU/g of tissue in spleen, liver and lungs compared to WT mice. Pulmonar granulomata of IL-18 and CD95KO were found to be greater both in size and number of fungal cells compared with WT mice. In addition, we demonstrated a delayed formation of compact granulomata, what only occurs by day 30 after infection, while in WT mice this occurred at day 15 . We also verified that the levels of IFN- $\gamma$, IL-4, IL-10 e IL-12 (evaluated by ELISA) were similar between IL-18KO and WT mice, suggesting that lack of IL-18 in paracoccidiodomycosis may be counterbalanced by other cytokines. Flow cytometric analyses are underway to detect CD95L expression and fosfatidylserine exposure in splenic and pulmonar cells of IL-18 and CD95KO during the course of disease. By these means we intend to correlate these data with eventual induction of apoptosis in these cells.

Keywords: Paracoccidioidomycosis. Granulomata. Apoptosis.

Financial support: CAPES and FAPESP

Oral Session 3

Chairs: Prof.Dr. Benedito Antonio Lopes da Fonseca and Profa.Dra. Nilce Maria Martinez Rossi

REGULATORY T CELLS (CD4 ${ }^{+} \mathrm{CD}^{+} 5^{+}$) IN LESIONS OF PATIENTS INFECTED WITH THE FUNGUS Paracoccidioides brasiliensis

Cavassani KA ${ }^{1}$, Campanelli AP ${ }^{3}$, Moreira AP ${ }^{1}$, Ferreira BR ${ }^{1}$, Dias ARV ${ }^{1}$, Mamede RCM $^{2}$, Martinez R ${ }^{2}$ \& Silva JS ${ }^{1}$

${ }^{1}$ Department of Biochemistry and Immunology, ${ }^{2}$ Internal of Medicine, School of Medicine of Ribeirão Preto -University of São Paulo, Ribeirão Preto, SP, Brazil. ${ }^{3}$ Department of Biological Science. School of Dentistry of Bauru, University of São Paulo. kcavassani@rpm.fmrp.usp.br

The long-term persistence of pathogens in a host is a hallmark of certain infectious diseases including tuberculosis, leismaniasis, and paracoccidioidomycosis (PCM). Patients with PCM usually show cellular immune hyporesponsiveness to fungal antigens and the mechanisms involved in the immunossupression include low IL-2 production, decreased IL-2 receptor expression, imbalance on cytokine production, apoptosis and CTLA-4 engagement. Since CTLA-4 is expressed in CD4+CD25 ${ }^{+}$regulatory T cells (Treg) and acts as a negative regulator of $\mathrm{T}$ cell activation in PCM, we investigated the involvement of Treg in establish latency in patients infected with Paracoccidioides brasiliensis. We found 3.5 to $16.8 \%$ of CD4+CD25+T cells in the skin and mucosal lesions from patients $(n=7)$. Further, $39.9 \%$ of $\mathrm{CD} 4{ }^{+} \mathrm{CD} 25^{+} \mathrm{T}$ cells also expressed CTLA-4 and CD45RO (89.6\%), as well as the chemokines receptors CCR5 (27.8\%), CCR4 (59.6\%), that can be associated with the migration of these cells to infected tissues. Indeed, the expression of TARC was detected in the lesions of these patients. In addition, the population of skin or mucosal derived $\mathrm{CD} 4^{+} \mathrm{CD} 25^{+} \mathrm{T}$ cells expressed intracellular IL-10 and TGF- $\beta$ (70.3\% and 90\%, respectively) and GITR (70\%). Altogether, our data showed that lesion-derived $\mathrm{CD} 4{ }^{+} \mathrm{CD} 25^{+} \mathrm{T}$ cells express characteristic markers of regulatory $\mathrm{T}$ cells suggesting that they are suppressing the effector immune response in the lesion site. Moreover, that Treg may mediate the latency in patients with PCM.

Keywords: CD4+CD25+ T Cells. Paracoccidioides brasiliensis. Latency.

Supported by: CNPq, FAPESP 


\title{
GENETIC POLYMORPHISM ANALYSIS OF PATIENTS WITH HANTAVIRUS CARDIOPULMONARY SYNDROME: PRELIMINARY RESULTS
}

\author{
Borges $\mathrm{AA}^{1}$, Campos $\mathrm{GM}^{2}$, Moreli $\mathrm{ML}^{2}$, Badra SJ${ }^{2}$, Souza RLM ${ }^{3}$, Donadi EA ${ }^{2}$ \& Figueiredo $\mathrm{LTM}^{2}$ \\ ${ }^{1}$ Departamento de Imunologia Básica e Aplicada, ${ }^{2}$ Departamento de Clínica Médica, Faculdade de Medicina de \\ Ribeirão Preto - USP, ${ }^{3}$ Instituto de Ciências Biomédicas - USP \\ alessandrabel@rpm.fmrp.usp.br
}

Hantavirus, members of the Bunyaviridae family, are rodent-borne viruses that cause a severe cardiopulmonary syndrome (HCPS) having a 50\% case fatality. Thirty cases of acute hantavirus infection have been diagnosed in Ribeirão Preto region since 1998. Hantaviruses infect cells by using $\beta 3$ integrins as receptors. This protein is present on the surfaces of platelets, endothelial cells, and macrophages. Since $\beta 3$ integrins are able to regulate vascular permeability and platelet function, polymorphisms in chain $\beta 3$ could be correlated to hantavirus pathogenesis and to the outcome of infections. Knowing that $\beta 3$ chains contain epitopes related to the Human Platelet Alloantigens System (HPA), we studied the HPA in patients having HCPS. Using a polymerase chain reaction with allele-specific primers (PCR-ASP) method, we determined the allelic polymorphisms of four HPA systems in six patients with HCPS and in 50 blood donors. HPA 1a/1a genotype ocurred in 4 HCPS patients $(66,7 \%)$ and in 36 blood donors (72\%), HPA 1a/1b genotype ocurred in 2 patients $(33,3 \%)$ and in 13 blood donors (26\%), HPA 1a/4b ocurred just in 1(2\%) blood donor, and HPA $6 \mathrm{~b}$ alleles were absent from tested population. The comparison of gene frequencies of the alleles HPA-1a, HPA-1b, HPA- $4 b$ and HPA- $6 \mathrm{~b}$ between HCPS patients and blood donors was not significant. This preliminary data indicate that HPA alleles are not a risk factor for HCPS.

Keywords: Hantavirus. HPA. $\beta 3$ Integrins.

Financial support: FAPESP

\section{GALECTIN-3 INTERFERENCE IN THE COURSE OF Paracoccidioides brasiliensis INFECTION}

\author{
Ruas LP \& Roque-Barreira MC \\ Department of Cellular and Molecular Biology Medical School of Ribeirão Preto - University of São Paulo \\ lpruas@rpm.fmrp.usp.br, mcrbarre@fmrp.usp.br
}

Paracoccidioides brasiliensis is the causative agent of paracoccidioidomycosis, a systemic mycosis that is geographically confined to Latin America, mainly to Brazil. Paracoccidioidomycosis is a chronic granulomatous disease, whose granulomatous reaction is assumed to be an efficient form of pathogen contention, blocking the systemic dissemination of the fungus. Galectin-3 is a $\beta$-galactoside-binding animal protein. It is secreted by various cell types including monocytes, macrophages, and epithelial cells, and it is involved in the granuloma formation, since it is a chemoattractant for monocytes and macrophages We have observed that there is an increasing expression of galectin-3 by inflammatory cells that constitute the granuloma at the lungs of C57Bl/6 mice infected with P. brasiliensis. Wild type and galectin-3 knockout mice were infected with $\mathrm{Pb} 18$ isolate and they were sacrificed at 15,30 e 45 days post infection. After 15 days a granulomatous inflammatory process in the liver and spleen was observed in the wild type animals, and it was maintained until 45 days post infection. In the galectin-3 knockout animals these granulomatous inflammatory responses are absent up to the 30 days at the spleen and up to the 45 days at the liver. These data suggest that galectin- 3 might interfere in the course of $P$. brasiliensis infection.

Keywords: Paracoccidioides brasiliensis. Galectin-3. Granuloma

Financial support: FAPESP 


\title{
INTRANASAL BCG IMPROVE HUMORAL IMMUNE RESPONSE ELICITED BY DNA-hsp65
}

\author{
Gonçalves EDC, Bonato VLD \& Silva CL \\ Department of Biochemistry and Immunology, School of Medicine of Ribeirão Preto - University of São Paulo \\ eduardo@cpt.fmrp.usp.br
}

In a previous work we showed that a DNA-hsp65 vaccine encoding the heat shock protein from Mycobacterium leprae (hsp65) presented prophylactic and therapeutic effect in a model of experimental tuberculosis. Recently, a new strategy involving DNA vaccination, described as "prime-boost", has been one possible approach to improve immune responses. In the present work, we evaluated the role of BCG in this strategy. Four groups of BALB/c mice were immunized as describe following. A: (first group) were immunized with BCG by subcutaneous route (i.n.), B: (second group) are immunized by BCG with intranasal route (s.c.), C (third group) and D (fourth group), were immunized with DNA-hsp65 by intramuscular (i.m.) route. After 15 days, the booster was done in group A and B with DNA-hsp65 by i.m. route. The C group was immunized with BCG by s.c. route and D group is immunized with BCG by i.n. route. Fifteen days after the last immunization, we evaluated antibody production. Our previous results showed that mice primed with BCG by i.n. route followed with DNA-hsp65 (group B) presented significant levels of specific IgG2a, in comparison with group A. On the other hand, mice primed with DNA-hsp65 followed with BCG as booster by two routes, presented lower titer of antibody production than group B. The prime-boost strategy using BCG by i.n. route as prime enhanced the total $\mathrm{IgG}$ and $\mathrm{IgG} 2 \mathrm{a}-$-specific antibody production, suggesting a Th1 pattern of immune response. This polarization is very important against mycobacterial infection. Additional studies are underway in order to determine the cell types involved in this induction and the protection against $M$. tuberculosis challenge in all groups of mice.

Keywords: DNA Vaccine. hsp65. Tuberculosis.

Financial support by: FAPESP

\section{CYTOKINE PATTERN DEVELOPED BY TICK-RESISTANT GUINEA-PIGS}

\author{
Franzin AM, Yamauchi LM, Silva JS \& Ferreira BR \\ Departamento de Bioquímica e Imunologia. Faculdade de Medicina de Ribeirão Preto - USP \\ franzin@rpm.fmrp.usp.br
}

Guinea-pigs develop resistance to ticks already in the second tick contact, differing to what happens to dogs and mice, which do not develop a protective response. It was described that leukocytes from tick-infested guinea-pigs proliferate intensively in response to Con-A and tick saliva, and develop a strong delayed-type hypersensitivity reaction to ticks in a cutaneous test to tick antigens. On the other hand, mice and dogs demonstrate an immediate hypersensitivity reaction and their leukocytes do not proliferate when stimulated in culture. It was also shown that mice develop Th2 cytokine profile in response to ticks. In the current study we investigated the cytokine expression in the skin and lymph nodes of tick saliva-inoculated and tick-infested guinea-pigs. Total RNA was extracted from the skin and lymph nodes of animals three times inoculated with saliva ( $40 \mu \mathrm{L}$ / guinea -pig, intradermally ) and several cytokine gene expression was determined by RT-PCR, using specific primers designed from them RNA sequences of guinea -pig cytokine $s$. The results demonstrate that the successive inoculation with tick saliva induces increase in the expression of IL-12, IFN- $\gamma$, TNF- $\alpha$, TGF- $\beta$ and IL-10, in both skin and lymph nodes, suggesting that guinea-pigs develop a mixed pattern of immune response to ticks. The pattern of cytokine expression in response to tick infestation is still under investigation and added to the current data, will contribute for the elucidation of the immune mechanisms which can lead to resistance against $R$. sanguineus ticks.

Keywords: Ticks. Cytokines. Guinea-pigs.

Supported by: FAPESP, CNPq 


\title{
THE IMMUNE RESPONSE AGAINST Lutzomyia longipalpis SALIVA
}

\author{
Carregaro $V^{1}$, Campanelli AP², Milanesi $C^{1}$, Dias ARV, Brodyskin $C^{3,5}$, Barral AM ${ }^{3,4,5}$, \\ Barral-Netto $\mathrm{MN}^{3,4,5}$, Ferreira $\mathrm{BR}^{1} \&$ Silva $\mathrm{JS}^{1}$
}
${ }^{1}$ Departamento de Bioquímica e Imunologia, Faculdade de Medicina de Ribeirão Preto - USP, Departamento de Ciências Biológicas, ${ }^{2}$ Faculdade de Odontologia de Bauru, USP, ${ }^{3}$ Centro de Pesquisa Gonçalo Muniz, Fundação Oswaldo Cruz (FIOCRUZ), ${ }^{4}$ Faculdade de Medicina, Universidade Federal da Bahia, ${ }^{5}$ Instituto de Investigação Imunológica - Salvador, Brasil vanessa@rpm.fmrp.usp.br

Experimental models of leishmaniosis have only rarely attempted to reproduce the biology of natural transmission, including a consideration of dose, saliva and site of inoculation. There is an important factor in natural transmission, since that individual who lives in endemic areas normally are exposed to uninfected sand flies bites, and almost never develops disease. These individual may develop response due to IFN- $\gamma$ production at the site of parasite delivery. However, the effects of saliva vector or saliva preexposure are not understood. Our aim is to investigate the response immunological against Lutzomyia longipalpis saliva using a natural model of infection in susceptible (BALB/c) and resistant (C57BL/6) mice, inoculated with or without salivary gland sonicate (SGS) into ear dermal. Initially, by histopatologics analyses could notice an increase of cells in the ear, mainly in BALB/c after the inoculated once with SGS. When we analyzed the inflammatory infiltrated, observed an increase in the number of CD4, CD8, CD4CD25, F4/80 and GR1 positives in presence of SGS, while the number of CD11b/CD11c was constant, strain mice independently. Preexposure to SGS lead to a significant decrease in number the cell types analyzed, less CD8 that was increased. The same response was seen in the mice that received SGS or preexposed to and challenged with lower doses of the Leishmania braziliensis. Additional studies are underway in order to evaluate the role of saliva in the local production of cytokines and parasite burden. So far, the Lutzomyia longipalpis saliva, but not pressensibilization were able to recrute leucocites in the site of inoculation.

Keywords: Leishmania braziliensis. Lutzomyia longipalpis. Saliva.

Financial support:CAPES, FAPESP

\section{CELLULAR AND HUMORAL IMMUNE RESPONSE INDUCED BY SUBUNIT VACCINE BASED ON POLY LACTIDE-CO-GLYCOLIDE POLYMERS (PLGA) MICROSPHERES CARRYING RHSP65 PROTEIN AND IMMUNOSTIMULANTS}

\author{
Santos SA, Lima KM, Brandão IT, Rodrigues Jr JM \& Silva CL \\ Rede - TB. Centro de Pesquisa em Tuberculose, Departamento de Bioquímica e Imunologia, Faculdade de Medicina de Ribeirão Preto- USP \\ sasantos@ rpm.fmrp.usp.br
}

Previous studies have showed that immunization of BALB/c mice with rHsp65 protein expressed from J774-hsp65 cells or plasmid DNA, induced protective immunity against infection with Mycobacterium tuberculosis H37Rv (MTB) similar to that induced by BCG. However, rHsp65 in Freund's incomplete adjuvant has no significant protective effect. It was also demonstrated that cationic liposomes carrying rHsp65 protein induced protection, although not as long-lasting as that conferred by the same antigen applied as a DNA vaccine. To improve the immune response, biodegradable microspheres based on PLGA were used as antigen (rHsp65) carrier but this formulation did not induce significative protection against MTB. However, microspheres containing rHsp65 plus two different immunostimulants ( $\mathrm{A}$ or $\mathrm{B}$ ) were effective to protect mice against infection. Now is under investigation, the immune response elicited in BALB/c mice, after i.m. injection of $5 \mathrm{mg}$ of each formulation. Preliminary results showed that 30 days after immunization, both formulations containing A or B immunostimulants induced similar specific IgG1 and IgG2a titers in the serum compared with control (without immunostimulants). These formulations also induced similar levels of IFN- $\gamma$ or IL-12 production by total spleen cells while IL-10 and IL-4 were reduced when compared with control. These data suggests that formulations containing immunostimulants (A or B) could be more effective to modulate the immune response to Th1 pattern than the formulation without immunostimulants, which induced more $\mathrm{Th} 2$ cytokines release.

Keywords: rHsp65. Tuberculosis. Subunit Vaccine.

Supported by: FAPESP, CNPq. 


\title{
Oral Session 4
}

\author{
Chairs: Dr. Alexandra Ivo de Medeiros and Dr. Beatriz Rossetti Ferreira
}

\section{INTRACELLULAR TRAFFIC OF PLGA MICROSPHERES CARRYNG pCDNA3-hsp65 AND CHARACTERIZA- TION OF THE IMMUNE CELLS INVOLVED IN THE UPTAKE PROCESS}

\author{
Trombone APF ${ }^{\mathrm{I}}$, Coelho-Castelo AAM ${ }^{1}$, Lima KM${ }^{1}$, Jamur $\mathrm{MC}^{2}$, Oliver $\mathrm{C}^{2}$, Palma PVB ${ }^{3}$, \\ Brandao $\mathrm{IT}^{1}$, Masson $\mathrm{AP}^{1}$, Rodrigues Júnior $\mathrm{JM}^{1} \&$ Silva $\mathrm{CL}^{1}$ \\ ${ }^{1}$ Rede TB. Centro de Pesquisa em Tuberculose, Departamento de Bioquímica Imunologia, ${ }^{2}$ Departamento de Biologia Celular, \\ Molecular e Biogentes Patogênicos, Faculdade de Medicina de Ribeirão Preto - USP, ${ }^{3}$ Hemocentro, Ribeirão Preto \\ apfavaro@yahoo.com
}

Our previous studies have demonstrated that immunization with plasmid DNA encapsulated in PLGA microspheres is able to induce an efficient immune response. However, the uptake, the traffic of microspheres in the cell, and the transcription/production of the message for hsp65 protein are not completely known. Our aim is to elucidate the interaction of microspheres with the immune system cells, in order to develop more effective gene delivery systems. We treated J774 and Raw cells with pcDNA3-hsp65 encapsulated in PLGA microspheres marked with 6-coumarin, to monitor their intracellular traffic. After $24 \mathrm{~h}$ the microspheres can be located in the lysosomes by second marker, LysoTraker Red dye. Additionally, we determined the distribution in vivo of DNA encapsulated in PLGA.Intramuscular administration resulted, after 7, 15 and 30 days, in widespread dissemination of microspheres marked with 6-coumarin analyzed by flow cytometry. However, analyzing mRNA expression by Real Time PCR, we found that message for hsp65 protein was detectable, after 15 days, only lymph nodes, spleen, kidney and lung. Moreover, we showed that after intramuscular immunization, PLGA microspheres was phagocyted by macrophage and dendritics cells (in lymph nodes), and expression of the activation surface markers CD80, CD86 and MHC class II were increased. Additional studies are underway in order to clarify the kinetics and the route of intracellular traffic of microspheres, and, together with the current data, will contribute to the knowledge of the interaction of immune cells with PLGA microspheres.

Keywords: PLGA Microspheres. pcDNA3-hsp65. Intracellular Traffic.

Supported by: FAPESP, CNPq.

\section{DECREASED MACROPHAGE PHAGOCYTOSIS OF APOPTOTIC THYMOCYTES INDUCED BY PHYSIOLOGICAL STRESS}

\author{
Sesti-Costa R, Baccan G, Chedraouli-Silva S \& Mantovani B \\ Departament of Biochemistry and Immunology, Medical School of Ribeirão Preto, University of São Paulo. \\ renatasesti@ hotmail.com.
}

Apoptosis and the subsequent phagocytic clearance of senescent cells have central roles in many fundamental biological processes. It is known that phagocytosis of apoptotic cells is under influence of soluble mediators in vitro, such as cytokines, prostaglandines and glycocorticoids, however, the situation in vivo is evidently more complex. Many reports show stress-induced changes in the immune system, nevertheless, no information is available as to the influence of stress in phagocytosis of apoptotic cells - an important event in the innammation resolution. In this study, we observe the influence of physiological stress, induced in mice by exposition to low temperature, in the macrophage capacity to ingest apoptotic thymocytes. The levels of corticosterone, adrenaline and noradrenaline (the main hormones released dunng stress) were dosed after each type of stress, and these concentrations were used in the in vitro assays. It was observed that acute stress $\left(-15^{\circ} \mathrm{C}, 10 \mathrm{~min}\right)$ doesn't change neither the interaction nor the phagocytosis of apoptotic thymocyte by pentoneal macrophages (normal and activated by LPS). The prolonged stress $\left(4^{\circ} \mathrm{C}, 4 \mathrm{~h}\right)$, however, decreased phagocytosis (but not the interaction) of apoptotic thymocyte by LPS-activated macrophages, without changing phagocytosis by normal macrophages. This effect was attributed to corticosterone. Some reports show that the apoptosis increases during stress. Since our results show that phagocytosis of apoptotic cells decreased in this condition, the stress could be a factor implicated in autoimmune diseases, since persistent apoptotic remains, such as nucleossomos have been involved in some diseases.

Keywords: Macrophage. Apoptosis. Stress. 


\title{
Hsp65-DNA VACCINE (PVAX-HSP65) STIMULATES DIFFERENTLY HUMAN MACROPHAGES AND DENDRITIC CELLS
}

Franco LH, Silva CL, Trombone APF, Coelho-Castelo AAM \& Bonato VLD

Rede TB, Biochemistry and Immunology Department, Faculdade de Medicina de Ribeirão Preto, University of São Paulo, Brazil. luishennque@cpt.fmrp.usp.br

A DNA vaccine that codifies a $65 \mathrm{kDa}$ protein (hsp65) from Mycobacterium leprae presented a prophylactic and therapeutic effect in a model of experimental tuberculosis. This vaccine was derived from the pcDNA3 vector by insertion of a $3.3 \mathrm{~kb}$ fragment corresponding to the $M$. leprae hsp65 gene and the CMV intron A. A different vaccine characterized by the pVAX plasmid containing the hsp65 gene (pVAX-hsp65) is now available to our group. This construct is allowed for clinical trials because the pVAX plasmid contains the gene for kanamicin resistance. We addressed the question whether the pVAX-hsp65 DNA vaccine would be able to activate human antigen presenting cells, such as macrophages and dendritic cells. For this purpose, monocytederived macrophages and dendritic cells from peripheral blood were cultured with or without pVAX-hsp65. Forty-eight hours later, we evaluated the cellular phenotype, as well as cytokine and chemokine production by these cells. Our results show that 48 hours after stimulation with pVAX-hsp65, macrophages and dendritic cells were able to endocyte the DNA vaccine, and it reached the nucleus. Moreover, forty-eight hours after stimulation, dendntic cells up-regulated CD80 expression and secreted high levels of TNF- $\alpha$ and IL-12p40. On the other hand, macrophages presented no change on the expression of surface markers, however, they secreted high levels of TNF- $\alpha$, IL-6 and IL-10. Our results suggest that pVAX-hsp65 DNA vaccine seems to stimulate differently human macrophages and dendritic cells.

Keywords: Human Macrophages. Human Dendritic Cells. DNA Vaccine.

Financial support: FAPESP

\section{EARLY RELEASE OF NITRIC OXIDE BY BRAZILIAN Orthobunyavirus-INFECTED MACROPHAGES}

\author{
Livonesi MC, Badra SJ \& Figueiredo LTM \\ Laboratório de Virologia, Unidade Multidepartamental de Pesquisa em Virologia, Faculdade de Medicina de Ribeirão Preto - USP, \\ pink@rpm.fmrp.usp.br
}

Oropouche, Caraparu, Guamá, Guaroa and Tacaiuma viruses belong to the Orthobunyavirus genus of the Bunyaviridae family. These viruses are transmitted by mosquitoes and have been associated with febrile illness as well as meningoencephalitis in humans. However, the pathogenesis of the Brazilian Orthobunyavirus including the host cells that participate of the infection process is unknown. Macrophages, centrally involved in both the innate and adaptive immunity, play a role in antiviral defense, but have a conflicting contribution on viral spread. Macrophages can be initial hosts for infection and can transport viruses into a variety of host organs including the brain. Therefore, the goal of this work is to investigate the susceptibility of murine macrophages (J774 lineage) to Brazilian Orthobunyavirus infection. Preliminary results showed that macrophages are permissive cells to the infection by Oropouche, Caraparu, Guamá, Guaroa and Tacaiuma. The viruses, mainly Oropouche, produced an early cytopathic effect and high cell mortality up to 7 days after infection. Moreover, macrophages infected by Oropouche and Caraparu viruses released nitric oxide (NO) at 48 hours after infection, while Guaroa and Tacaiuma viruses released NO throughout experimental period, producing the highest levels after 48 hours. Cells infected by Guamá virus did not produce NO. Our results suggest that macrophages are susceptible to the infection by Brazilian Orthobunyavirus and these cells could play a role on virus infection control.

Keywords: Macrophages, Orthobunyavirus, Nitnc Oxide 


\title{
RESISTANCE TO UNDECANOIC ACID INCREASES PROTON TRANSPORT THROUGH PLASMA MEMBRANE AND PROTEASE SECRETION IN THE DERMATOPHYTE Trichophyton rubrum
}

\author{
Peres NTA ${ }^{1}$, Nozawa SR ${ }^{1}$, Cursuto-Santos ${ }^{1}$ JR, Rossi A ${ }^{2}$ \& Martinez-Rossi NM ${ }^{1}$ \\ ${ }^{1}$ Departamento de Genética. ${ }^{2}$ Departamento de Bioquimica e Imunologia. Faculdade de Medicina de Ribeirão Preto - USP \\ nalu@usp.br
}

Dermatophytes are fungi that invade keratinized tissue as skin, hair and nails of human and animals, producing an infection generally cutaneous and restrict to the nonliving cornified layers. These fungi release a broad spectrum of exoenzymes which are important factors for invasion and utilization of host tissue and must be advantageous for fungal spread. The most prevalent dermatophyte is Trichophyton rubrum. Undecanoic acid (UDA) is a medium-chain fatty acid with antimicotic properties, which inhibits the cellular respiration, the production of lipase and keratinase, stimulates the phospholipase A secretion, and at high concentrations inhibits the biosynthesis of several phospholipids in T. rubrum. However, the mechanisms underlying the resistance to UDA are unclear. We isolated a T. rubum UDA resistant mutant, by UV irradiation, to evaluate genes and cellular processes that could be involved in this resistance. We used Differential Display technique (DDRT-PCR) and the plaque assay to measure exocellular proteases secreted by both strains. Some of the bands from DDRT-PCR were sequenced and the BLAST analysis showed 7 hypothetical proteins, and a plasma membrane $\mathrm{H}^{+}$-ATPase protein (expressed by the resistant strain and confirmed by reverse northern blotting). The estimation of secreted protease activity showed that the resistant strain secrets higher levels as compared to the wild type. Since the comparative results showed variations on different cellular processes as protease secretion and expression of a proton transporter gene, we suppose that a complex cellular mechanism involving these processes are important to T. rubrum adaptation to UDA exposition.

Keywords: Dermatophytes. Tnchophyton rubrum. Undecanoic Acid.

Financial support: CNPq, CAPES, FAEPA e FAPESP.

\section{Oral Session 5}

\author{
Chairs: Prof.Dr. José Elpidio Barbosa and Profa.Dra. Isabel de Miranda Santos
}

\section{DIFFERENTIAL GENE EXPRESSION PROFILE OF LYMPHOMONONUCLEAR CELLS OF RECENTLY DIAGNOSED TYPE 1 DIABETES MELLITUS PATIENTS}

\author{
Rassi $\mathrm{DM}^{1}$, Junta $\mathrm{CM}^{2}$, Fachin $\mathrm{AL}^{2}$, Sandrin-Garcia $\mathrm{P}^{2}$, Feniandes $\mathrm{APM}^{3}$, de Freitas $\mathrm{MCF}^{4}$, Foss $\mathrm{MCF}^{4}$, \\ Sakamoto-Hojo ET ${ }^{2,6}$, Passos GAS ${ }^{2,7} \&$ Donadi EA ${ }^{1,5}$ \\ ${ }^{1}$ Departamento de Imunologia Básica e Aplicada, ${ }^{2}$ Departamento de Genética, Faculdade de Medicina de Ribeirão Preto - USP. \\ ${ }^{3}$ Departamento de Enfermagem Geral e Especializada, Escola de Enfermagem de Ribeirão Preto - USP. ${ }^{4}$ Divisão de Endocrinologia, \\ Departamento de Clinica Médica, ${ }^{5}$ Departamento de Clinica Médica, Faculdade de Medicina de Ribeirão Preto - USP. ${ }^{6}$ Departa- \\ mento de Biologia, Faculdade de Filosofia, Ciências e Letras de Ribeirão Preto - USP. ${ }^{7}$ Disciplina de Genética, \\ Faculdade de Odontologia de Ribeirão Preto - USP. \\ dianerassi@hotmail.com
}

Insulin-dependent diabetes mellitus (IDDM) or type 1 diabetes mellitus (DM-1) is an organ- specific autoimmune disease caused by the selective destruction of the pancreatic $\beta$ cells by inflammatory cells, especially auto-reactive $\mathrm{CD} 8{ }^{+} \mathrm{T}$ lymphocytes. Clinical manifestations usually appear when approximately $80 \%$ of the cells are destroyed. DM-1 is one of the commonest chronic disease among young children and teenagers. The etiology of DM-1 is considered to be multifactonal, involving the participation of genetic, immunologic and environmental factors. 
Since recently diagnosed DM-1 patients represent the end stage of pancreatic $\beta$ cell destruction by several lymphomononuclear cells, and since there are few studies evaluating the genome wide gene expression in DM-1 patients, in this study we evaluated the differential large scale gene expression using cDNA microarrays of $\mathrm{T}$ and $\mathrm{B}$, and monocyte cells, admittedly implicated in the pathogenesis of the disease in recently diagnosed patients. cDNA microarrays represents a powerful tool for the study of human diseases, specially autoimmine diseases since they represent clinical disorders with a heterogeneous course. In addition, considenng that HLA class II profile may influence the expression of HLA molecules on the surface of peripheral blood cells, and considering that the mechanisms by which HLA class II susceptible alleles drive the auto-immune response have not been elucidated, we intend to further stratify DM-1 patients according to the HLA class II profile.

Keywords: Type I Diabetes Mellitus. Gene Expression. HLA Class II (CLI).

Financial support: FAPESP

\title{
EFFECT OF DNAhsp65 IMMUNIZATION ON DIABETES INDUCED BY MULTIPLE LOW-DOSE STREPTOZOTOCIN
}

\author{
Santos Jr· RR ${ }^{1}$, Sartori A ${ }^{2}$, Vilella CA ${ }^{3}$, Bonato VLD ${ }^{1}$, Coelho-Castelo AAM ${ }^{1}$, Zollner RL ${ }^{1} \&$ Silva CL ${ }^{1}$ \\ ${ }^{1}$ Centre for Tuberculosis Research, School of Medicine of Ribeirão Preto, University of São Paulo, Brazil. ${ }^{2}$ Biociences Institute, \\ UNESP, Botucatu, São Paulo, Brazil. ${ }^{3}$ Laboratory of Clinical Immunology, UNICAMP, Campinas, Brazil.
}

We recently described the prophylactic and therapeutic effect of a DNA vaccine containing the gene of hsp65 from Mycobactenum leprae on tuberculosis. In addition to using a protein that is highly homologous to the correspondent mammalian protein, the vector carries $\mathrm{CpG}$ motifs. These characteristics could trigger or worsen an auto-immune disease. In this study we investigated the effect of previous vaccination with DNAhsp65 on a diabetes model induced by streptozotocin (STZ). C57BL/6 mice were immunized with pcDNA3hsp65 by intramuscular ( 3 doses of $100 \mu \mathrm{g}$ ) or intradermal ( 3 doses of $1 \mu \mathrm{g}$ ) route by Gene Gun. Animals not immunized or that received only the vector were used as control groups. Two weeks after the last dose, the animals received 5 doses of STZ $(40 \mathrm{mg} / \mathrm{Kg}$ ) by i.p. route on consecutive days. Glucose concentrations were determined in blood weekly collected from the retro-orbital venous plexus. On the fifth week the animals were sacrificed and the splenic cells were stimulated in vitro with recombinant hsp65 protein or Con A. Supernatants were assayed by ELISA for TNF- $\alpha$ concentration. Both immunization routes significantly increased the glucose senc levels. Vector alone induced similar increases in glucose levels. Production of TNF- $\alpha$ was significantly higher in the STZ group, in comparison with control groups (non-treated, vaccinated or that received only vector). In addition, the immunization by intramuscular route, but not by intradermal route, was associated with TNF- $\alpha$ levels higher than those detected in the STZ group. New protocols, including lower vaccine concentrations and alternative routes of DNA administration, are being planned to further investigate this effect on experimental diabetes.

Keywords: Diabetes. DNA Vaccines.TNF- $\alpha$

Supported by: Fapesp, Cnpq, Faepa.

\section{THE ROLE OF METHYLATION STATE OF ALU REPETITIVE SEQUENCES IN THE PATHOGENESIS OF SYSTEMIC LUPUS ERYTHEMATOSUS}

\author{
Tamia-Ferreira MC ${ }^{1}$, Donadi EA ${ }^{2}$ \& Passos $\mathrm{GAS}^{1,3}$ \\ ${ }^{1}$ Grupo de Imunogenética Molecular, ${ }^{2}$ Departamento de Clínica Médica, Faculdade de Medicina de Ribeirão Preto - USP, ${ }^{3}$ Discipli- \\ na de genética, Faculdade de Odontologia de Ribeirão Preto - USP \\ passos@rge.fmrp.usp.br
}

Epigenetic alteniations in genomic dna encompass cytosine methylation in cytosine and guanine (cpg) 
dinucleotide islands. The epigenetic aberration in regulatory dna sequences may be responsible for the emergence of changes in the immune system in patients with systemic lupus erythematosus (sle). alu repeats are especially rich in cpg dinucleotides. To determine whether specific elements of the genome of sle subjects exhibit a unique pattern of methylation-sensitive restriction sites, we probed the methylation state of alu repetitive dna sequences in lupus peripheral lymphocytes. Genomic dna was digested with the methylation-insensitive enzyme mspi, which recognizes and cuts at both ccgg and cmcgg restriction sites, or with the methylation sensitive enzyme hpaii, which cuts only unmethylated ccgg restriction sites. Samples were loaded, size-fractionated on a $2 \%$ agarose gel, and blotted onto hybond n+ filters (amersham) by vacuum transfer. Subsequently, filters were hybridized to an alu probe consisting of a $210 \mathrm{bp}$ fragment derived from alu "pv-pr" by molecular amplification. in dna samples isolated from sle patients, hpaii site demethylation was detectable in about $20 \%$ of the samples, indicating that their alu sequences are demethylated. Our data showed that the extent of alu methylation in sle lymphocytes was lower than that of control samples. This epigenetic study may give us clues towards elucidation of the pathogenesis of sle and development of new therapeutic strategies for this disease.

Keywords: Sle. Methylation. Alu sequences.

Supporred by CAPES, FAPESP

HLA AND TNF MICROSATELLITE POLYMORPHISM IN BRAZILIAN PATIENTS PRESENTING WITH SYSTEMIC SCLEROSIS

\author{
Wastowski IJ ${ }^{1}$, Simóes RT ${ }^{2}$, Rassi DM ${ }^{1}$, Louzada $\mathrm{P}^{3}$ \& Donadi EA ${ }^{1,3}$ \\ ${ }^{1}$ Department of Immunology, ${ }^{2}$ Department of Pathology, ${ }^{3}$ Department of Medicine, Faculty of Medicine of Ribeirão Preto, \\ University of São Paulo, Brazil \\ wastowski@yahoo.com.br
}

Systemic Sclerosis (SSc) is a connective tissue disorder, whose etiology is associated wIth immune system abnormalities and genetic factors. In addition, the cell traffic between the fetus and mother during pregnancy and the graft versus host disease (GVHD) reaction induced by fetal's cells against mother's cells have been associated with SSc pathogenesis too. Tumor necrosis factor- $\alpha$ (TNF- $\alpha$ ) is a potent inflammatory cytokine, which is increased in serum of SSc patients. In humans, TNF genes are located within the HLA region and at last fIve microsatellites (a, b, c, d and e) are described in this region. These microsatellites are multiallelic and like HLA genes have been associated with GVHD, which skin involvement resembles SSc. Objective: To evaluate the TNF microsatellite (a, b, c, d and e) and HLA class II (HLA-DR/DQ) polymorphisms. Methods: Blood samples were collected from 40 patients with SSc and 99 healthy controls. DNA was extracted using a salting out procedure. TNF microsatellite and HLA alleles were identified using sets of SSP. Statistical analysis was performed using the GENEPOP software and the Fisher exact test. Results: Compared to controls TNFa8 allele $(\mathrm{p}=0.01)$ and TNFb0303 $(\mathrm{p}=0.02)$ and TNFb0404 $(\mathrm{p}=0.006)$ genotypes were overrepresented in SSc patients. No significant differences were observed in relation to HLA allele frequencies. Conclusion: The TNFb (0303 and 0404 genotypes) and TNFa8 allele association with SSc has not reported before and may be involved in SSc pathogenesis.

Keywords: HLA. TNF. Systemic Sclerosis. 


\title{
CHARACTERIZATION OF AN INTERFERON-GAMMA BINDING PROTEIN IN TOXOPLASMA GONDII
}

\author{
Oliveira LL, Panunto-Castelo A \& Roque-Barreira MC \\ Departamento de Biologia Celular e Molecular, Faculdade de Medicina de Ribeirão Preto-USP, \\ licursi@rpm.fmrp.usp.br
}

One of the essential events of toxoplasmosis is the induction of numerous immune modulators that activate immune responses. The IFN- $\gamma$ plays major role in immuneresponses in toxoplasmosis. The IFN- $\gamma$ controls indirectly a lot of events on mammalian immune responses against $T$. gondii, but there are few studies reporting its direct action of this cytokine over the parasite. Objectives: Evaluate the IFN- $\gamma$ binding protein expression in T. gondii. Methods: To evaluate the interaction between IFN- $\gamma$ and $T$. gondii, we accomplished binding assays with the recombinant IFN- $\gamma$ cy tokine and with monoclonal antibody anti-IFN- $\gamma$. The protein was characterized by SDS-PAGE and Western blotting. Results: we can conclude that there is a difference between tachyzoites from infected mice and tachyzoites from cell culture. Flow cytometry analysis with IFN- $\gamma$ and anti- IFN- $\gamma$ antibody detected an IFN- $\gamma$ binding protein on tachyzoites surface, but parasites from infected mice are covered by endogenous IFN- $\gamma$. The IFN- $\gamma$ binding protein was characterized like a $35 \mathrm{KDa}$ protein. Conclusion: The identification of the surface binding protein of the parasite opens new perspectives to understand how IFN- $\gamma$ can interact directly with $T$. gondii.

Keywords: Tonoplasma Gondii. IFN- $\gamma$ Binding Protein.

Supported by CAPES

\section{GENETIC POLYMORPHISMS IN SEVERE ASTHMA}

\author{
Guideroli $\mathrm{LOO}^{1}$, Deghaide NHS ${ }^{1}$, Wastoswki IJ ${ }^{1}$, Simóes RT ${ }^{2}$, Oliveira FR ${ }^{3}$, Zago MA ${ }^{4}$ \& Donadi EA ${ }^{1,3}$ \\ ${ }^{1}$ Laboratóno de Imunologia Molecular, Hospital das Clínicas da Faculdade de Medicina de Ribeirão Preto - USP, ${ }^{2}$ Departamento de \\ Patologia, Faculdade de Medicina de Ribeirão Preto - USP, ${ }^{3}$ Departamento de Clinica Médica, ${ }^{4}$ Laboratório de Hematologia do \\ Hospital das Clínicas da Faculdade de Medicina de Ribeirão Preto - USP
}

Asthma is a chronic disease whose major characteristic are: variable degree of airflow obstruction (usually reversible), bronchial hyperresponsiveness and airway inflammation. The pathogenesis of severe asthma is poorly understood. It is not clear which genetic or enviromental factors may be most important to the development of severe disease. The rate of hospital addmitance_due severe asthma has been increasingly in many countries, including Brazil, and is responsible for high mortality and morbidity.

In this study, we evaluated the polymorphisms of genes associated with inflammation (TNF, GR, and MPO), metabolism (CYP2B6, MTHF, GST, VDR and TPMT) and multidrug resistance (MDR1) which may be linked to severity of asthma. Preliminary results showed that the genotype $\mathrm{TNFe} 0103(\mathrm{p}=0,0329)$ and the alleles TNFel $(p=0,0056)$ and TNFe3 $(p=0,0130)$ were overrepresented in patients with severe asthma compared with controls.

Since TNF may be associated with the induction of inflammation, and since it may be potentially increase broncoconstriction, the association of severe asthma with TNF polymorphisms may be relevant to uncover the pathogenesis of severe asthma.

Keywords: Polymorphisms. Genes. Asthma

Support: CNPq 


\title{
IMMUNE RECONSTITUTION AND PRODUCTION OF INTRACELLULAR CYTOKINES BY T LYMPHOCYTE POPULATIONS FOLLOWING AUTOLOGOUS HEMATOPOEITIC STEM CELL TRANSPLANTATION FOR AUTOIMMUNE DISEASES
}

\author{
Farias $\mathrm{KCRM}^{1}$, Oliveira $\mathrm{MCB}^{2}$, Stracien $\mathrm{ABPL}^{2}$, Godoi $\mathrm{DI}^{2}$, Moraes $\mathrm{DA}^{2}$, Coutinho $\mathrm{MA}^{2} \&$ Voltarelli $\mathrm{JC}^{2,3}$ \\ ${ }^{1}$ Department of Biochemistry and Immunology, ${ }^{2}$ Bone Marrow Transplantation Unit, \\ ${ }^{3}$ Department of Clinical Medicine, School of Medicine of Ribeirão Preto, University of São Paulo
}

High-dose immunosuppression therapy (HDIT) followed by autologous hematopoietic stem cell transplantation (AHSCT) has emerged in the past few years as a new treatment strategy for patients with severe and refractory autoimmune diseases (AID). The goal of this therapy is to intensively suppress the immune system and then rescue the patient from prolonged cytopenias or hematopoietic failure by infusing autologous hematopoietic stem cells. We examined five patients with multiple sclerosis (MS) and two with systemic lupus erytematosus (SLE) who were treated with HDIT followed by AHSCT. Complete clinical remission of the AID was achieved in these patients (except for one MS patient), and has been sustained for several months without the use of immunosuppressive drugs. The immune reconstitution of the various lymphocyte populations and the production of intracellular cytokines by in vitro activated lymphocytes were analyzed by flow cytometry. We observed rapid hematopoietic recovery and partially impaired immune reconstitution in these patients. Recovery of natural killer cells was prompt, while B cells reconstituted only after 3- 6months post-transplant. Generally, the "Umber of $\mathrm{CD}^{+} \mathrm{T}$ cells normalized 3 months after transplantation, however markedly reduced $\mathrm{CD}^{+} \mathrm{T}$ cell numbers were observed during the first months post-transplant, with inverted CD4/CD8 ratios. T cells detect-

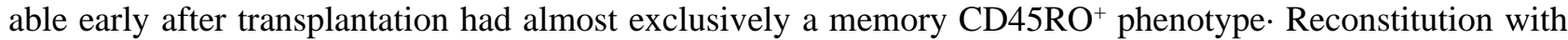
naive CD45RA ${ }^{+} \mathrm{T}$ cells was very slow within the first months post-transplant. A high percentage of $\mathrm{T}$ cells expressed activation markers, such as HLA-DR and Fas. SLE patients, who are known to have a Th2 cytokine skewing, showed a Thl cytokine profile after transplantation. On the other hand, patients with MS, a prototypical Thl autoimmune disease, showed gradually reducing numbers of Thl cells and an increased percentage of Th2 cells after transplantation. These latter observations may be the key factors explaining therapeutic benefit of HDIT followed by AHSCT in autoimmune diseases.

Keywords: Autoimmune Diseases. Autologous Hematopoietic Stem Cell Transplantation. Immune Reconstitution. 